Entrevistas

Volume 11 - $2021 \mid$ n. 8

\title{
Entrevista com Lisete Regina Gomes Arelaro
}

Como parte das comemorações dos 10 anos da Revista Fineduca, entrevistamos ${ }^{1}$ Lisete Regina Gomes Arelaro, professora emérita da Faculdade de Educação da Universidade de São Paulo, presidente da Fineduca na gestão 2015-2017 e uma das primeiras mulheres no Brasil a pesquisar financiamento da Educação. Nesta conversa (de 3h30), realizada em 22/12/2020, Lisete nos conta uma história de vida em defesa da Educação, que começa quando ainda era estudante e se estende para os diversos cargos e funções que ocupou. Ressalta o papel educativo de todas as suas experiências. Realista e confiante na luta por uma educação pública, laica e de qualidade socialmente referenciada para todos/as e pela construção de uma sociedade mais justa, igualitária, solidária e democrática, Lisete nos inspira como pesquisadores e militantes da Educação Pública. Nosso objetivo inicial era discutir a política de fundos, mas isso deve ficar para um artigo que ela escreverá com Juca Gil, pois faltou tempo...

Fineduca: Fale de você, Lisete, e sua trajetória, por favor.

Eu sou campineira. Sou de família de classe média, com pais com graduação universitária. Chamo-me Lisete Regina, o que já define de onde a gente está falando. Entrei no Instituto de Educação Carlos Gomes, uma das escolas públicas mais conceituadas da cidade e ela foi minha segunda casa durante muitos anos. Entrei na pré-escola, meus pais tiveram que pedir para eu entrar um pouco antes, porque todos os meus amigos eram mais velhos e já estavam na escola, e eu gostava de estar na escola, tanto que eu tinha cinco minutos para chupar chupeta fora da sala de aula, porque eu era pequenininha. E eu fiz três anos e meio de préescola, que era inusual naquele tempo. Fiz quatro anos de primário, quatro anos de ginásio e três de normal. Naquele tempo, o ensino fundamental era de oito anos, os primeiros quatro eram chamados ensino primário e quatro correspondiam ao segundo ciclo, chamado de ginásio. E, no ginásio, a escola fez uma opção pela Escola Nova. Em Campinas, você tinha duas grandes referências de escolas públicas, o Culto à Ciência, que era para quem queria fazer Medicina, Engenharia e tal, era para os meninos, e o Instituto de Educação Carlos Gomes, que era para as meninas. Não era assim que era argumentado, mas era assim na prática. Era, portanto, considerada uma das melhores escolas. Os professores realmente eram competentes em termos de conteúdo, porque o critério de correspondência de um bom professor naquela época era se a pessoa realmente dominava o conteúdo, e muito bem, mesmo que ele fosse autodidata e não tivesse completado um curso superior.

É importante dizer isso, porque os concursos para professor não eram como são agora, eram entrevistas e o candidato tinha que ter domínio do conteúdo. E o Instituto de Educação, ao aderir à Escola Nova, trouxe uma orientadora educacional, chamada Maria Angélica, que

1 Entrevistadores da Fineduca: José Marcelino de Rezente Pinto. Professor da Universidade de São Paulo, Ribeirão Preto. Editor da Revista Fineduca; Márcia Aparecida Jacomini. Professora da Universidade Federal de São Paulo. Editora da Revista Fineduca. 
Entrevista com Lisete Regina Gomes Arelaro

introduziu algumas mudanças. Ela introduzir, por exemplo, Educação Sexual no final dos anos 50 é uma coisa que eu acho muito interessante.

Eu gosto de falar isso, Zé e Márcia, porque é um momento que eu vivi que não voltou ainda. Eu não quero ser saudosista, mas é sobre gestão democrática. O diretor da escola chamavase Welman Galvão da França Rangel. Só usava terno, todos os dias, era um homem tradicional, porém era, contraditoriamente, um gestor democrático, a gente jamais o chamaria de "você", mas ele acreditava na gestão democrática com participação dos alunos. Nós tínhamos representantes de classe, nos reuníamos e tínhamos um local específico, uma sala específica para o grêmio estudantil Castro Alves, do qual eu tive o prazer de ter sido presidente. E, de fato, participávamos em cada semestre de uma reunião para avaliar os professores. Essa é uma coisa muito interessante. Não era para avaliar professor para pô-los para fora, era para avaliar como é que nós estávamos recebendo os conteúdos que eram transmitidos em aula. E, antes disso, a gente fazia reunião em cada classe, avaliando cada professor e, portanto, você sabe, éramos adolescentes, então também existia as nossas maldades contra alguns. Mas, do ponto de vista concreto, era muito interessante pois a gente levava contribuições efetivas. Esse é um processo que eu não vi voltar a ocorrer. E não passava nem na nossa cabeça, nem do professor e muito menos do diretor que a gente, eventualmente, pudesse despedir um professor, ou tivesse esse poder, porque não era assim que funcionava. Os professores eram efetivos e tinham muita consciência da sua estabilidade. $\mathrm{E}$, de fato, era para dizer: "Olha, nós estamos aprendendo. Não estamos aprendendo. O que você fala a gente entende, não entende", está certo?; "Você é grosseiro, você falou tal coisa. Nós não gostamos de tal questão" e assim por diante. Então, ressalto isso, eu estou dizendo essa questão, porque eu tive a oportunidade de discutir com o Demerval Saviani sua posição em relação à proposta da Escola Nova, dizendo um pouco brincando: "Demerval, meu querido amigo..." que, enquanto ele estava lá no seminário, nós estávamos fazendo outra coisa. Nós estávamos, inclusive, envolvidas em política estudantil.

E não dava para falar mal da Escola Nova, porque a Escola Nova não era só desgrudar a carteira, porque a nossa carteira até era grudada e a gente sentava de dois em dois. Não era isso. Só que acontecia uma reestruturação do ensino e da educação, e não era homem com homem e mulher com mulher. Podia ser menina com menino e assim por diante. Então, foi uma escola em que, em termos da Educação Sexual, introduziu modificações inclusive nessa questão atualmente superada de menina é rosa, menino é azul. Eu já ouvi, quando eu tinha 11 anos de idade, que não era só rosa e azul, que o mundo era mais complicado que isso. É muito interessante a gente pensar nessa questão.

E quando eu estou chegando na sétima série, mais ou menos (considerando a seriação atual), nós convivíamos com a Teologia da Libertação. E, a partir daí, portanto, viro uma militante veja só - católica, entro para a JEC, Juventude Estudantil Católica, mas meu vínculo mais forte era com o Partidão (Partido Comunista Brasileiro). E foi nesse momento, do alto dos meus 12, 13 anos, 14, que eu fui ler Marx. Só para vocês entenderem, porque no Partidão tinha que ler Marx; era tarefa política. Então, só para vocês entenderem que, essas coisas todas, nós tínhamos um grupo de teatro, então existiam várias linhas, o anarquismo também era uma variante importante, portanto, andar de preto era uma coisa moderna, chique, avançada etc. Eu li Sartre, L'Être et le Néant (O Ser e o Nada) em francês, porque a gente aprendia francês no ginásio. E eu não entendi nada. Depois, quando eu fui ler mesmo, já 
adulta, eu vi que eu não tinha entendido nada, mas a gente fazia pose, porque, puxa, ler em francês era o "must", né?

Então, só para saber, portanto, eu começo, a partir do curso normal (1960), a ter uma atividade política com vários grupos e movimentos. Como vai ser uma proposta da UNE (União Nacional dos Estudantes), a alfabetização era uma obrigação de todos. Então nós criamos um grupo, fomos para uma paróquia de um padre que também era meio Partidão, meio esquerda, era muito interessante, para dar aula usando o método Paulo Freire. Paulo Freire nem pode imaginar o que é que nós achávamos que era o método Paulo Freire, porque nós não sabíamos nada disso, nunca tínhamos lido nada sobre isso. Mas a gente sabia que tinha um método que era diferente, passava slide e a gente passava com aquelas caixinhas de sapato, sabe? Que eram as mais primitivas, que a gente fazia no fundo de quintal, a gente fazia imagens do que a gente entendia que era o cotidiano.

Bom, meu pai era advogado e eu era excelente aluna de Matemática. Minha professora de Matemática, Profa. Heloísa, era uma católica progressista que acreditava na Escola Nova, ela não se conformava que eu tivesse ido fazer Pedagogia, porque, para ela, eu tinha que fazer Matemática. No dia que eu descobri que você podia provar um teorema por absurdo, eu me dediquei a isso e todo dia eu tinha uma nova invenção, que deu muito trabalho para ela. Mas aí, é o seguinte, eu fiz o Normal e, vocês vejam, eu peguei uma mudança também no curso. O curso tinha Física e Biologia, fiz Biologia, tinha Biologia Educacional, a gente vinha para São Paulo, no Hospital das Clínicas. Lembrando que o Brasil ainda era bem mais rural do que atualmente.

Eu nasci em 1945, só em 1960 o Brasil vai começar o processo de mudança do campo para as cidades, mas, até essa época, o Brasil era um país cerca de $60 \%$ rural. Portanto, a professora primária tinha que ser a líder de onde ela estivesse. Fazer um parto era uma emergência que podia acontecer com qualquer um. Então, a gente vinha para o Hospital das Clínicas, assistia um parto e ajudava em um parto. Eram duas sessões, primeiro você assistia, depois você ajudava em um parto, quem não desmaiava, bem entendido, porque eles achavam que isso envolvia algumas questões básicas, como é que corta o cordão umbilical etc. Quer dizer, como é que você salva uma criança se você tiver que ser uma enfermeira improvisada.

Sim, também fazíamos, no Normal, análise do tipo de sangue, ou se você era RH positivo ou negativo, essas coisas, porque, se tinha laboratório na escola, então você tinha condição. Eu confesso para vocês que uma das coisas mais emocionantes que existia, quando você estava na quarta série do ensino primário, era você saber que ia poder entrar na sala de ciências, que era o laboratório. Aí sim, você era gente, porque tinha lá a caveira. Então, durante o meu curso Normal, dentro dessa perspectiva da Teologia da Libertação, o padre Celso Queiroz é que nos coordenava, hoje ele é bispo, está velhinho, mas está vivo. Eles eram decididamente progressistas, senão de esquerda, talvez como o frei Beto ${ }^{2}$, mas eles eram progressistas. Tanto que, na ditadura, eles ajudaram a tirar vários militantes do País, quando eu não tinha mais alternativa usava a estrutura da igreja, deixava gente dormindo na casa deles, pegava a perua deles para retirar quem estava sendo perseguido. Era bom sair com a proteção daquela perua. A gente tirou muita gente do País com a ajuda deles. Mas fazer o Normal e dar aula, inclusive com o método Paulo Freire, e alfabetizar desse jeito que eu estou dizendo para

\footnotetext{
2 Carlos Alberto Libânio Christo.
} 
vocês, tudo atrapalhado, mas efetivo, porque as pessoas aprendiam. Acho que a gente misturava a cartilha com o Paulo Freire, acho que era uma confusão, porque nós não tínhamos acesso a nenhum material específico naqueles anos.

Eu me entusiasmei pelo curso de Pedagogia, porque, vejam vocês, eu achava que queria construir um outro país e construir um outro país significava passar por uma questão pedagógica. Era uma ilusão total, faltava leitura sobre socialismo efetivamente, mas eu achava isso, eu estava convicta. Então, o meu pai, que era advogado, logicamente ficou bastante decepcionado, porque, para ele, pedagogia era cursinho de mulher, certo? Eu, toda avançadinha lá, como é que ia fazer Pedagogia? Eu tinha que ficar com o escritório dele. Até eu já tinha feito algumas defesas. Mas eu acho que eu sou uma advogada da educação e, portanto, estou no caminho certo. Fiz Pedagogia na Universidade Católica de Campinas, não era PUC (Pontifícia Universidade Católica) ainda, porque PUC tem que ser benta pelo papa. Então era UCC, como era chamada, e para fazer Pedagogia só tinha uma turma diurna de 30 alunos. Ao mesmo tempo, eu estudava piano, já estava formada em piano e, portanto, eu trabalhava num Conservatório. Quando entrei no primeiro ano de Pedagogia, fiz duas coisas: primeiro prestei dois concursos, um no SESI (Serviço Social da Indústria) e outro na rede pública estadual. Neste último, pela minha classificação, fui para o Vale da Ribeira, dei aula um mês. Era um barato, porque era uma área rural, muito diferente da minha experiência urbana, mas era inconciliável voltar do Vale da Ribeira, ainda mais naquela época, para Campinas no mesmo dia para assistir aula. Então, acabei desistindo. Eu dava aula de Teoria e Solfejo e Composição no Conservatório Musical Campinas. E, depois, eu tinha prestado concurso no SESI. Hoje eu sei exatamente que você pode fazer um concurso sem vaga, quer dizer, a empresa faz um concurso de "reserva de vagas", mas naquela época, para mim, não era. Para mim era o seguinte: "Se eu passei em primeiro lugar, eu tenho que ter uma vaga. Que negócio é esse?", e briguei. Acho que enchi tanto a paciência deles, que teve uma professora que ficou grávida e eu assumi uma sala de aula do $1^{\circ}$ ano primário, que tinha 50 alunas, 30 matriculados e 20 anexos. Por quê? Porque a gente dava aula na escola onde havia funcionado o colégio Pio XII, um antigo seminário, que hoje é uma universidade, inclusive é faculdade privada, que ficava perto do bosque, do lado do bosque em Campinas, que era considerado - imagina - distante para chuchu. Imagina, perto do bosque, é igual ao zoológico daqui de São Paulo, era longe. E o que acontece? A gente atendia uma população muito pobre e tinha irmãos que a mãe não podia deixar em casa, tinha que trabalhar, e, portanto, essas crianças que ficavam sem ter para onde ir, iam para onde tivesse lugar.

A sala em que eu trabalhava era uma grande sala do seminário e, como se sabe, toda sala de seminário é muito grande. Cabiam as 30 mais os 20 brincando, e era assim. Essa foi a minha primeira experiência, só para vocês entenderem. Tinha três meninos coreanos, cujos pais tinham morrido na guerra, no contexto da guerra; cada vez que passava um avião, eles desmaiavam. Só para vocês terem uma ideia de como são interessantes essas coisas. E a gente discutiu na sala, as crianças entenderam, eles eram extremamente solidários. E tinha uma menina que tinha bastante deficiência, que precisava ser levada ao banheiro, ainda usava fralda no primeiro ano, e isso também era dividido entre nós, alunas e professora. Eu acho que aprendi mais com eles do que eles comigo.

$\mathrm{E}$, depois, discutimos também - como eu tinha saído de uma escola avançadinha - tivemos alguns problemas na escola, introduzimos Educação Sexual, porque os meninos eram muito 
grandes, os que vinham para o segundo ano, terceiro ano, quarto ano e teve pais que protestaram, porque chegavam lá e eu tinha o quê? 20 anos, nem isso. "Que negócio é esse de uma menina de 18 anos estar falando para o outro de 16 uma coisa assim?". Mas foi muito interessante, foi uma experiência que me definiu, no sentido de que eu queria ser professora. Então, continuei, eu era colega da Regina Duarte no Conservatório. Quando eu acabei essa experiência na escola do SESI, já estávamos em 1964, vem o golpe.

Eu confesso que levei um susto, porque nós estávamos iniciando a nossa vida política, não imaginávamos que não ia ter reação. Todos nós esperávamos, a gente até perguntava: "Cadê as armas? Cadê a reação? Cadê o Leonel Brizola? Cadê o Jango ${ }^{3}$ ?". Foi um pouco uma decepção. Sabem que eu estudei com o Luiz Carlos Freitas? Luiz é de um ano antes de mim. Foi meu colega, a gente virou amigo nessa época. E nós, portanto, 1963, 1964, 1965, em 1966, quando eu estava no quarto ano de Pedagogia, nós fizemos o que ficou conhecido como a primeira passeata de estudantes contra a ditadura militar. Claro, lá estavam todos, todas as musiquinhas da UNE: "Amigo, o quê? O quê? O quê? O que você vai fazer?". Tudo isso, nós estávamos nessa questão e, como tal, tínhamos atividades culturais como forma de denúncia e de ampliação da militância. E eu, apesar dos vínculos com a Igreja, não fui para a JUC (Juventude Universitária Católica); já tinha as minhas dúvidas religiosas. Para mim foi mais fácil ter a minha primeira relação sexual do que sair da Igreja. Eu achava que tinha uma missão política e religiosa.

A missão política era mudar o mundo e, a religiosa, era explicar o mistério da Santíssima Trindade. Uma coisa modesta. Porque eu realmente até hoje acho que uma das coisas mais interessantes da Igreja Católica é essa ideia de um Deus em três pessoas. Acho que é riquíssimo, acho que traduz verdadeiramente os nossos diferentes lados. Sou de signo gêmeos, é impossível se dedicar a uma coisa só, então tem que ter uma mistura nessas coisas. E nós fizemos essa nossa passeata, nós saímos todos com lenço preto amarrado nos braços e nos rostos. A polícia deu em cima de nós; entramos em uma igreja, eles entraram na igreja, igreja de Nossa Senhora do Carmo, que era do lado do chamado Pátio dos Leões, que é onde ficava a reitoria da Universidade. Mas é aquela história, Campinas possuía 300 mil pessoas, meu pai era um advogado. Evidentemente ele conhecia todos os delegados de polícia. E foi lá: "Que negócio é esse de prender a minha filha?". Então soltou todo mundo. Ainda era a fase 'um' do golpe, digamos assim.

No final do ano de 1966, eu vim para São Paulo, prestei um teste no Centro Regional de Pesquisas Educacionais Prof. Queiroz Filho, na cidade universitária, para um programa de assistência técnica em educação chamado "PATE", que era coordenado pelo Prof. José Mário Pires Azanha, e que atuava no Norte e no Nordeste. Era a forma como o Carvalho Pinto atuava. Ele dizia: "Dinheiro não dou, mas emprestar pessoal para melhorar a educação do Norte e Nordeste, sim". E aí era uma coisa interessante. Eu vim para São Paulo, fiz o meu teste, passei no teste e o perfil de pessoas que o José Mário escolheu era, de um lado, pessoas que tinham experiência fundamentalmente em ensino, pessoas que alfabetizavam, que sabiam Matemática, qualquer outra coisa. Naquele ano, eu diria, ele escolheu pessoas avançadinhas, no sentido socialista do termo. Participaram Eliana Rolemberg, Elba Sá Barreto, entre outras. Eu fui para Alagoas e, a Elba e a Eliana, foram para Sergipe, e nós

3 João Goulart, presidente do Brasil de 1961 a 1964. 
tínhamos um grupo que era bastante interessante. Eu não tenho dúvida que, às vezes, divido a minha vida em várias partes, mas é assim: antes e depois de Alagoas. Porque uma coisa é você ser campineira, chamada Lisete Regina, ser militante, tocar piano. E aí você chegar em um estado que é basicamente rural, pobre economicamente, é uma coisa muito diferente. Aí tem o seguinte, eu, em tese, era da AP (Ação Popular) ${ }^{4}$ ou pelo menos eu era amiga das pessoas da AP. Foi com eles que fui me aproximando dos grupos clandestinos. Mas fui militante mesmo da Ação Popular Marxista-Leninista, que acrescentou mais um "M", que era Maoísta. E, quando estava na Universidade, a grande discussão que tínhamos era "Que universidade é essa?", você sabia que estava perguntando que país que você quer. Que país é este? Que país é este, que país você quer construir? Esse eu acho que é um dado de diferença da nossa geração. Você podia falar: "Não gosto de como está", ok, mas eu diria que você era chamado a responder como modificá-lo. Você era pressionado a responder esse tipo de coisa. Depois você decidia, porque ninguém ia te forçar.

Mas, de todo jeito, era mais politizado. Quando a gente fala na "despolitização da educação", é nesse sentido de que o País se perdeu. Quer dizer, quem é que discute o Brasil como um país concreto onde você vive? O que é a desigualdade no Brasil? Claro que, nesse momento, está aí Josué de Castro ${ }^{5}$ já denunciando essas questões. As Reformas de base eram medidas que, para nós, eram muito sérias. Então, reforma agrária era uma delas, eu às vezes brinco, porque digo o seguinte: "Olha, fui pessoalmente chamar o Plínio de Arruda Sampaio, no primeiro ano de Pedagogia, portanto, em 1963, para que ele fosse falar sobre reforma agrária. Nós estamos em 2020, quase 2021, e, se vivo estivesse, a gente chamaria o Plínio de Arruda Sampaio para discutir a importância da reforma agrária e do Estatuto da Terra". Então, eu já não era da JUC (Juventude Universitária Católica), mas eu era ainda católica e estava nessa minha saída lenta, gradual e dolorida da Igreja. Mas os padres progressistas praticamente estavam na AP. Eles eram a alma da AP.

E, do ponto de vista concreto, vão aparecendo muitos grupos políticos clandestinos que queriam mudar o País para torná-lo mais justo. São mais de 15 grupos políticos, que é alguma coisa que hoje a gente perdeu, pois cabem na palma de uma mão. E, portanto, as variações, as divergências eram muito comuns. $E$ isso tudo era muito rico, porque as coisas estavam acontecendo também em um ritmo acelerado, a discussão sobre as reformas de base e depois a pressão em cima do Jango, não era uma coisa pequena, mas as greves foram se articulando e foram acontecendo no Brasil de maneira muito intensa. Em 1964, em Campinas, nenhum de nós foi molestado, porque eles estavam atrás do que eles chamavam dos "comunistas" tradicionais, pessoal do Partidão mesmo. Tinha um padre que recebia as prostitutas na paróquia e que já era conhecido. Eles prendiam os mesmos, porque estavam catalogados. $\mathrm{E}$ eu diria que a juventude foi poupada nessa "primeira fase" da ditadura. Então, fiquei em Alagoas em 1967, e não fui presa em Ibiúna, porque viajei um dia antes. Em Maceió, o secretário de educação era loiro de olhos azuis. Ele era filho de um jornalista que foi assassinado, porque andou escrevendo coisas contra o governo. Sua mãe assumiu o lugar do marido usando um pseudônimo e ela foi assassinada com ele no colo. Mas eu aprendi

4 Organização política de esquerda extraparlamentar, criada em junho de 1962 por militantes estudantis da Juventude Universitária Católica (JUC) e de outras agremiações da Ação Católica Brasileira.

5 Josué Apolônio de Castro, mais conhecido como Josué de Castro, médico, nutrólogo, professor, geógrafo, cientista social, político, escritor e importante ativista brasileiro do combate à fome. 
algumas coisas com esse secretário de educação. Primeiro, ele tinha algumas medidas de segurança, pelo que ele tinha passado. Alguns diziam que ele era do SNI (Serviço Nacional de Informações); se ele era mesmo um agente do SNI, não sei, mas ele só se sentava em lugares, por exemplo, de costas para uma parede de verdade, que um tiro não passasse.

E lá, em Alagoas, por incrível que pareça, eu fiz formação de professores com o método Paulo Freire, usado de modo um pouco mais correto do que eu tinha feito quando estava no curso normal. O que eu não sabia, a gente também inventava e ponto final. Mas, a nossa surpresa, é que as pessoas aprendiam. Porque a nossa bibliografia era atualizada. No curso normal, nós passávamos uma semana dando aula na escola de aplicação, com acompanhamento dos nossos professores de Prática de Ensino. Era outra condição de trabalho. Lembrando que nós éramos 30 alunos. Então, é claro que era muito diferente. As condições para poder colocar isso em prática eram outras.

Quando a gente chegou em Maceió, o Estado tinha que fazer uma reforma administrativa, que obviamente a ditadura estava obrigando todos a fazerem, conforme exigência do DecretoLei $n^{\circ}$ 200/1967. Então, a minha primeira tarefa era fazer um diagnóstico da situação da secretaria estadual de educação. E aí, nós constatamos coisas incríveis. O Conselho Estadual de Educação, por exemplo, não tinha atas de suas reuniões. Você fala: "Mas como assim?". Não, tinha um caderninho de uma secretária. Quer dizer, se ela morresse ou se ela jogasse fora o caderninho, acabou a história do Conselho Estadual. Bom, a outra coisa que eu aprendi e que eu valorizei, aprendi tanto que eu acabei me entusiasmando, que acabei valorizando muito, foi a localização das escolas. Isso para nós, hoje, pode parecer óbvio, mas não é bem assim, porque as creches que são alugadas, ninguém sabe se estão no lugar que dizem que estão. Mas lá era diferente, porque não se sabia onde se localizavam as escolas públicas estaduais. Então você falava: "Mas, gente, vocês respondem para o MEC (Ministério da Educação) e para o IBGE (Instituto Brasileiro de Geografia e Estatística). Como é que vocês fazem?". Aí a resposta, depois que a gente tinha virado amigo, era: "A gente inventa. Mas nós temos uma pessoa aqui que sabe onde fica".

Por isso que em 1970, quando teve o grande projeto da Operação Escola, apesar de ser uma medida do governo militar, eu achava bom. Porque, seja em que língua for, para o que for, saber onde estão as escolas, até para mandar merenda, é fundamental. Lembrando, inclusive, que nessa época tudo era centralizado. Então, se você não tinha endereço, você não recebia nada. Então, esse ano foi um ano que aprendi muito. Nós estávamos lá com um professor mais velho que nós, chamado Aquiles Archero Júnior, que já tinha livro publicado de Sociologia Educacional. Evidentemente que aprendi, muito rápido, que o alagoano era extremamente machista. Uma coisa é ser reacionário, outra coisa é ser machista. E Campinas podia ser elitista, mas não era machista do jeito alagoano.

Eu estive em Pernambuco e lá o PCB era muito forte e eu lembro que consegui visitar as ligas camponesas já no final, também 1967, graças a um amigo do Miguel Arraes ${ }^{6}$. E nós assistimos lá um grupo que descobriu que o dono da fazenda tinha misturado o café que eles tinham separado, para pagar menos e continuarem meeiros endividados, mas assim que o cara deu o preço, dizendo que não tinha qualidade o café, os camponeses não tiveram dúvidas, foram lá e atearam fogo: "Perdemos nós, perdeu você". Então, é outra forma de resolver os

6 Político brasileiro, foi prefeito de Recife, deputado estadual e federal e governador do estado de Pernambuco, por três vezes. 
problemas. Primeiro camponês não fica falando como eu falo, ele fala muito pouco. Eles são silenciosos e agem.

A volta para São Paulo. Voltei e fui trabalhar com o Prof. José Mário7; ele estava na Secretaria de Educação do estado de São Paulo, na administração Ulhoa Cintra. Eu pude participar diretamente da elaboração das provas que viabilizaram a aprovação de $92 \%$ dos alunos que saíram do quarto ano primário e foram para o primeiro ano ginasial. E aí deu naquela confusão que vocês conhecem bem, que é o direito de todos continuarem no ginásio. Nós tínhamos 10 escolas primárias para cada uma com ginásio e isso levou àquela maluquice de ter três turnos, quatro turnos, cinco turnos. Mesmo assim, o Prof. José Mário se divertia, porque, como ele defendia a proposta do Sampaio Dória ${ }^{8}$, considerava que isto era um mal menor. Foi quando eu aprendi sobre o Sampaio Dória, nunca tinha ouvido falar dele. José Mário falava: "Olha, em uma situação limite...eu não estou defendendo isso, mas em uma situação limite, é preferível duas horas para todos do que quatro horas para alguns".

\section{Fineduca: Isso tem a ver com a existência do Exame de Admissão?}

Sim, o exame de admissão ainda era obrigatório. Então, a gente fez um exame de admissão sobre o conteúdo do que se ensinava no primário. Primeiro acabamos com essa história de que cada escola de elite fazia sua prova. Para passar do primário, na quarta série, para o primeiro ano do ginásio, o que seria hoje a sexta série, você fazia uma prova de conhecimentos gerais, de Português, Matemática, História e Geografia. E você tinha que tirar quatro em cada prova e cinco de média no mínimo. Uma questão que valia meio ponto no Instituto de Educação Carlos Gomes, por exemplo, era: "Quais são os países e capitais da Europa?". Só para entender o que significava um exame seletivo. Porque hoje Medicina tem 10, 11 alunos por vaga. Nós tínhamos 10, 11 alunos para disputar uma vaga na quinta série, no primeiro ano do ginásio. Então, por isso mesmo passou-se a inventar um quinto ano do ensino primário, que era para preparar para o exame de admissão. E depois o Prof. José Mário foi preso exatamente por conta dessa opção, por ampliar o acesso ao ginásio. A acusação política para a prisão do José Mário era que ele tinha propositadamente estimulado a balbúrdia - vou usar o termo aqui do atual governo. O que acontece? Na medida que os filhos passaram no exame, eu tinha uma fotografia de pais sacudindo os portões das escolas, principalmente das melhores escolas, dizendo: "Queremos vagas". Então, a classe média se mexeu muito com essa questão e a classe média-baixa também.

Então, tive a oportunidade de aprender muito com o Prof. José Mário. A luta pela escola pública era um traço marcante do José Mário. O respeito aos professores é outro. José Mário, quando cobrava professor, ele estava cobrando os colegas dele. Nunca fez uma acusação "eles", como se nada tivesse a ver com ele. E isso foi criando raízes em mim. Quer dizer, eu já tinha as minhas raízes, porque, fora a Universidade Católica de Campinas, eu sempre estudei em escola pública e isso era muito forte, e era uma excelente escola. E, não há dúvida

7 José Mario Pires Azanha foi professor emérito da Faculdade de Educação da Universidade de São Paulo e orientador de doutorado da Lisete.

8 Refere-se à proposta de Sampaio Dória de não reprovação das crianças na passagem do primeiro para o segundo ano primário. José Mario Pires Azanha foi responsável pela unificação do exame de admissão no estado de São Paulo, em 1969. Com a Lei n. 5.692/1971, que organiza o ensino em primeiro e segundo graus e torna obrigatório o ensino dos 7 aos 14 anos, o exame de admissão foi extinto. 
nenhuma, que ele acentuou os meus traços de defensora da escola pública em definitivo. Então, de lá para cá, desde 1967, eu sou uma militante da educação, da escola pública estatal laica e de qualidade para todos.

Então, em 1968, junto com a Elba de Sá Barreto, fomos juntas procurar fazer uma pósgraduação. Não existia mestrado e doutorado, fomos fazer uma pós-graduação na USP (Universidade de São Paulo), no meu caso em Ciências Sociais. Na época eu morava no Edifício Copan, onde tudo poderia acontecer e acontecia. Consegui ingressar e fui orientanda do Luiz Pereira. Eram 10 vagas. Eu lembro que o Luiz Pereira estava lá e eu, claro, tinha lido o livro dele ${ }^{9}$, que considero importantíssimo, que todo mundo tem que ler. Escolhi o Luiz Pereira porque ele tinha sido professor primário também.

E aí, o Luiz Pereira saiu na porta, onde estava havendo entrevistas, e falou: "Quem for pedagogo, pode sair da fila". E eu fui lá e falei: "Não, professor, espera um pouquinho, o senhor é pedagogo e o senhor saiu da fila?". Aí ele falou: "Entra". Foi assim que eu entrei com o Luiz Pereira. Eu era "bocuda", eu tinha sido presidente do Centro Acadêmico de Pedagogia. $E$, então, você vem com aquela empáfia de liderança estudantil. Só que é muito diferente, quando você chega na USP as pessoas brincavam e falavam para mim assim. "Olha, difícil aqui é encontrar onde é a aula de Sociologia 1, porque ninguém sabe". Era a aula do Luiz Pereira. E o sistema era muito interessante em termos de formação. Quem não era sociólogo de formação obrigatoriamente fazia Métodos e Técnicas de Pesquisa Social e Sociologia I e II, obrigatoriamente. E Métodos e Técnicas em Pesquisa Social, queria dizer estudar primeiramente Marx, Weber e Durkheim. E aí, eu fui fazer o curso do Prof. Florestan Fernandes, que também foi muito interessante, chamava Teorias Sociológicas, li tudo que tinha do Florestan. $E$ tinha aquela insegurança, porque eles eram minhas referências. $E$ aí, o Florestan falou o seguinte: "Bom, escuta, supondo que eu te aceite, você quer vir fazer meu curso por causa do quê?". E aí eu contei toda a minha experiência em Alagoas. Aí ele falou: "Lisete, por essa experiência você está no meu curso. Você não precisa saber aquilo, eu sei que você leu os meus livros e tal. Já leu, nem precisaria mais fazer o meu curso, mas, por essas razões aí, me interessa".

Fiz também o curso do Prof. Octavio lanni, Economia do Desenvolvimento. Para vocês saberem, em seu curso tinha os 10 regularmente matriculados e mais uns 20; era só discussão de grupo político. E aprendi muito na minha formação.

Aí eu prestei concurso público para professor de Educação, para atuar nos cursos Normais. Em 1968, o José Mário fez um concurso em que ele valorizou a nota; o critério principal era a nota do exame, depois contava os anos de magistério. Era o primeiro concurso para professor de educação. Então, eu passei muito bem. Mas como veio a nova Constituição, a Constituição de 1967 estabilizou os professores, mas em 1969 veio a nova Constituição, os estáveis entraram na justiça, porque, concursado tinha prioridade em qualquer profissão. Qualquer cargo, aliás. E foi dado ganho de causa aos professores. Então, a verdade é o seguinte, os professores do Caetano de Campos, eles não tinham prestado concurso, não porque eles não passassem, passariam muito bem, porque todos eles eram competentes, mas porque eles achavam que estavam lá há 15 anos e iam prestar concurso para quê? E nós contávamos com essas vagas. Isso só se resolveu em 1969, portanto em 1970 eu escolhi uma vaga e aí

9 Refere-se ao livro A escola numa área metropolitana. 
Entrevista com Lisete Regina Gomes Arelaro

escolhi o lugar que fosse mais próximo de São Paulo. Escolhi Conchas, e o Instituto de Educação Anísio Ferraz Godinho. Conchas era uma cidade de 10.000 habitantes, em desaparecimento na época, mas que atendia a região inteira, até praticamente Botucatu. Então, eu assumi as aulas e foi muito complicado, isso é que é um negócio sempre complicado de dizer, mas quem dava aula no segundo ciclo também dava aula para o normal e ganhava mais. E o nosso salário era de cinco salários-mínimos. Quando fui para Conchas, ainda estava fazendo o curso de pós-graduação. Quando eu cheguei lá, tinha um rapaz chorando, porque, vocês imaginem, em Conchas, se você não é professor, o que é que você faz? Nada, porque não tem emprego, não tem outra coisa para fazer.

O professor era jovem, recém-casado, com um filhinho, e aí eu conversei com ele e resolvi assumir 18 horas-aula, que me daria um salário que me permitia continuar pagando o aluguel no Copan, ir ao teatro, jantar e, logicamente, continuar o meu curso. Então escolhi 18 horasaula com Prática de Ensino e Administração Escolar e dava aula à noite, o que fez de mim a pessoa mais querida da escola. Primeiro, porque ajudei esse rapaz. Segundo, escolhi à noite, estava chegando a televisão e as novelas. A coisa mais disputada pelas professoras era assistir as novelas à noite. Imagine, eu era a primeira e única professora efetiva e a única professora efetiva mulher que escolheu dar aula à noite. Eu tinha meus interesses, porque eu queria ficar lá terça, quarta e quinta e ter segunda e sexta livres. E, nessa minha escolha, eu tinha meio guarda-roupa e uma cama em uma casinha coletiva. Essa questão eu só estou contando porque depois, no meu processo político, ela foi vital, pois todos os meus colegas me elogiaram.

Então, para vocês entenderem, estamos em agosto de 1970. Eu já tinha dado aula, quando trabalhava com o José Mário. Eu trabalhava meio período na Secretaria de Educação e dava aula no Colégio Estadual de Primeiro e Segundo Graus (CEPSG) Wolny de Carvalho Ramos em São Paulo, que era na Zona Leste. Era longe, porque a Radial Leste não existia. Então, tinha um trenzinho que passava às $6 \mathrm{~h} 30$. Ou você passava antes do trenzinho, ou então você perdia a hora, porque ele fazia 10 longos minutos de manobra. O portão abria 5 para as 7 , as aulas começavam às 7 horas, pontualmente. Era um grupo superanimado, cheio de "comunistas". Tinha uma diretora com quem, aliás, eu aprendi muito sobre gestão educacional. Ela dizia o seguinte: "Eu sei que a coisa mais importante na vida de vocês é horário de aula. Então, eu só não atendo quem está amamentando, porque se faz de duas em duas horas, o resto, eu topo. Minha condição: 'Quem escolhe horário tem janela', tem a janela que eu quiser dar, que eu puder dar. Quem não escolhe horário, topa o horário que eu montar, e eu garanto que não vai ter janela".

Então, vocês podem imaginar que eu tinha as minhas preferências. $E$ eu era uma pessoa que trabalhava segunda, sexta e sábado, que eram os dias em que ninguém queria trabalhar. Sábado a gente tinha aula até meio-dia. Eu fechava a escola e voltava segunda-feira antes das 5 para as 7, porque era eu que tinha que abrir o portão. Essa figura chamada "inspetor escolar" não existia. Foi uma experiência interessante e, só para vocês saberem, em um colégio estadual era permitido para o pedagogo dar aula de História, de quinta a oitava série no ginásio e Filosofia no Clássico e no Científico, como eram chamadas as modalidades do ensino médio. Eu dava História no que corresponderia hoje à sétima série. Sofria, porque era a idade que eu menos sabia trabalhar. Eu sabia trabalhar com os pequenos e com os "marmanjos". E Filosofia, os moleques gostavam muito e iam até me visitar em casa e o João 
(meu marido) dava risadas, porque ele falava: "Lisete, você tem 22 anos, eles têm 19 e 20, então eles estão te namorando, na verdade". Mas eles iam em casa e continuávamos as discussões feitas em classe, o que era muito interessante.

Mas eu também montei um curso em que eles tinham que ler "1984", de George Orwell. Também tinha os Aristóteles, mas a gente começava dos livros atuais. Então, era considerado por eles um curso superavançado, animado. Essas coisas que a gente faz quando está começando a lecionar e que não quer repetir o que é feito há 20,30 anos.

Então, eu já tinha essa experiência docente, trabalhava com o José Mário e, quando o José Mário saiu por conta da prisão, nós saímos também, pedimos demissão, por isso fui trabalhar no Colégio Wolny. E aí, a segunda orientadora educacional - o terceiro era o Celso Ferretti , mas a segunda estava em Conchas, era orientadora educacional no Instituto de Educação, e eu penso que eles foram colocados em institutos de educação como prioridade, pois só existiam 10 orientadores educacionais na rede estadual de ensino do estado de São Paulo. E ela veio trabalhar em São Paulo e aí ela um dia me telefonou em Conchas, onde eu trabalhava, e falou: "Lisete, você não poderia vir trabalhar conosco por uns 15/20 dias, talvez um mês? Pelo seguinte, como todas as coisas do Prof. José Mário foram jogadas fora aqui, vocês tinham feito um mapa com a localização de todas as escolas do estado e suas diferentes combinações com botões, de diferentes cores, que foi jogado fora junto. Você poderia nos ajudar a remontá-lo?". Eu já era apaixonada por mapas e nós tínhamos muitas variações de nomenclatura, lembram? Colégio Estadual e Escola Normal (CEEN); Colégio Estadual (CE), Escola Normal e Ginásio (ENGE); Ginásio Estadual (GE) ou Escola Primária (EP) ou Curso Primário Anexo (CPA) - privativo dos Institutos de Educação e mais as que o José Mário tinha "inventado": 167 escolas que eram Grupo Escolar e Ginásio (GEG). Ele juntou uma escola primária com um ginásio, já promovendo o avanço do que se defendia como oito anos de escolaridade, com continuidade. Bem, essa vinda me interessava, pois a minha atuação política era em São Paulo, não em Conchas. Me interessava vir, além do que me facilitava a frequência ao curso de pós-graduação. E concordei. Eles me convocaram por 30 dias pelo Diário Oficial e eu vim. Nesse meio tempo tive a minha primeira detenção no DOPS (Departamento de Ordem Política e Social), com Sergio Paranhos Fleury como delegado. $\mathrm{E}$ eu estou contando isso, porque isso vai gerar uma situação peculiar. Porque, assim que eu saí da prisão, isso era 24 de dezembro, do DOPS, eu fiquei lá uns 25 dias. Quando eu voltei, minha prisão tinha saído no jornal.

Eu fui presa no mesmo dia que a filha do Luís Carlos Prestes. Então, saímos em uma mesma notícia, quando eu voltei para a Secretaria era como se eu tivesse lepra, as pessoas não queriam encostar em mim: "Cuidado com ela, que é comunista" e a Secretária, Dra. Ester de Figueiredo Ferraz, me recebeu extremamente gentil e falou: "Você sabe que você vai responder a dois processos? Eu vou ter que abrir um processo contra você, que é um processo administrativo, mas você vai responder a um processo militar, está certo?". Na hora em que ela soube que eu fazia pós-graduação em Ciências Sociais, ela falou: "Está explicado". Para a Ester era mais simples. E foi muito interessante, porque ela fez uma coisa que poucos da esquerda de hoje fariam, pois eu ia ser descontada, não estive lá um mês. Ela escreveu atrás da folha de frequência que eu estive à disposição do DOPS por 24 horas todos aqueles dias. Portanto, é justo que ela receba seus vencimentos pois ela estava, na verdade, sob a tutela do Estado. Segunda coisa: ela teve que me convocar para ficar à disposição da 
Entrevista com Lisete Regina Gomes Arelaro

Secretaria, porque comunista não pode dar aula e eu tinha duas alternativas: uma que eu já conhecia do nosso querido anarquista Maurício, e querido professor de Sociologia, que toda vez perdia o cargo, prestava novo concurso e passava em $1^{\circ}$ lugar $^{10}$.

$\mathrm{E}$, em geral, as pessoas eram presas no local onde faziam suas atividades políticas, não era meu caso, porque eu era efetiva em Conchas. Então, respondi a um processo, que eu saiba nós somos dois ou três casos só, em que fomos absolvidos do processo administrativo. A comissão de sindicância ouviu até o dono do bar onde era parada do trem e do ônibus. Ambos paravam no mesmo lugar, no mesmo ponto, e esse bar era um local estratégico. E ele também respondeu no processo e disse: "Olha, a única vez que essa professora conversou comigo, foi porque ela esqueceu um vestido, parece que ela era madrinha de casamento [o que era verdade], e eles pediram para eu segurar o ônibus. Eles vieram de trem, voltaram de ônibus, ficaram o tempo de chegar na casa, pegar o vestido e ir embora". E os meus colegas disseram que eu era maravilhosa, porque eu tinha aceitado dar aula à noite. $\mathrm{E}$, com isso, eu tinha que esperar o processo militar. Então, isso me levou a trabalhar na Secretaria de Educação, convocada. E eles me colocaram para trabalhar no planejamento, para trabalhar com demanda, porque para eles número é suprapartidário. Então, isso me deu duas oportunidades.

Primeiro, foi aí que eu aprendi o que era orçamento. Eu fiz o primeiro curso de orçamentoprograma, que teve no estado de São Paulo. O orçamento-programa, em relação ao que se tinha, era um avanço, porque você tinha que dizer que atividades você pretendia realizar e para onde ia o dinheiro. Porque antes não, você escrevia "Ensino Primário", punha lá 15 milhões e ninguém nunca mais sabia o que era aquilo. Era uma farra. Eu acho que o que a gente avançou em termos de financiamento da educação é absolutamente incrível. Tudo bem que você fale: "É lento e gradual". Lento e gradual, mas eu peguei uma fase em que não tinha controle nenhum. Você escrevia qualquer coisa e o Secretário da Fazenda, o Secretário de Finanças também cortava qualquer coisa. Então, nem tinha como ser avaliado, porque, como não tinha especificação, qualquer coisa era uma especificação, valia para fins de prestação de contas. Além do que, sempre foi aquele mistério, porque ninguém tinha acesso à prestação de contas e o Tribunal de Contas nunca permitiu que alguém tivesse acesso aos processos, porque ali estavam todas as falcatruas que se quisesse fazer, e os amigos deles é que faziam.

Então, a situação era bastante complicada. Isso me ensinou que, toda vez que se falava que um diretor tinha roubado a escola porque não tinha seguido as normas, e muitas vezes participei de comissões processantes, eu sabia que era mais ignorância do processo contábil-financeiro do que roubo de fato. Porque o malandro é o que realmente conhece como fazer uma prestação de contas sem deixar vestígios. Eu convivia com malandros e sabia exatamente o que eles faziam. Então, vocês podem ver que eu também nunca fui pega em prestação de contas, porque eu aprendi com quem sabia ensinar melhor. E essa área foi uma que acabei me dedicando academicamente a partir daí. Quando entrou o Dr. José Bonifácio Coutinho Nogueira ${ }^{11}$, eu ainda não tinha sido julgada. Ele, em reunião, propôs dar um outro peso à seção de convênios, queria que fosse uma coisa séria, que houvesse realmente uma relação entre a proposta e a realização. Sei também que ninguém presta contas dos recursos recebidos do Estado: "Queria saber quem tem peito para assumir um negócio desses?". Do alto também da minha cara de

10 Referência a Maurício Tragtenberg, que foi cassado de dois cargos pela ditadura.

11 Foi nomeado secretário de Educação em 1975, pelo governador Paulo Egídio Martins. 
pau, falei: "Eu uso 46. Tenho peito para assumir isso". Assim que eu assumi a área de convênio, ele recebeu uma carta do SNI dizendo que eu era comunista, que eu ia ter acesso a informações privilegiadas e tal. E foi interessante que ele me chamou - foi a única vez que ele me chamou para falar sobre esse assunto, aliás -, ele pediu para eu fazer um resuminho da minha história, quantas vezes eu tinha sido presa, como é que era isso e tal. Eu tinha sido presa três vezes. Aí ele chamou e falou: "Lisete, essa carta aqui, eu quero te dizer que você inspira ciúmes. Isso aqui é dor de cotovelo, porque se o SNI quisesse mesmo ver você fora, eu recebia só um recado assim: 'Dispense-se a senhora Lisete'. Então isso aqui é de gente de lá, mas é ciumeira”. E me nomeou para um cargo em comissão. Para vocês verem que as contradições estão sempre presentes. E aí, eu fiz muito direitinho.

Mas eu estava um dia no MEC, fui buscar a minha carteirinha de professora, lembre-se que o reconhecimento era federal, e vejo um processo em cima da mesa, de um Colégio pedindo uma área para instalar uma escola de Educação Física, em nível superior. Eu falei: "Que engraçado, eu tenho um processo desses que é um convênio com esse colégio, mas é um terreno que está emprestado para eles, para cuidar de crianças no segundo turno e crianças que tivessem cometido delitos...". Chegando na secretaria, eu busco o processo e está lá o mesmo Colégio pedindo exatamente o mesmo terreno por mais 30 anos.

Na época, 30 anos era o período máximo de cessão. Hoje pode ser de 99, mas naquela época era até 30. E eu fiz um parecer negando a solicitação, porque, através do processo número tal, a área era a mesma, o que mostrava a má-fé da solicitação. A Profa Maria Aparecida Tamazo Garcia, diretora da Diretoria de Planejamento, minha chefe, assinou e o processo desceu para o secretário vetando a solicitação. Dois dias depois, uma sexta-feira, 6 horas da tarde, eu recebo na sala um general. Um general que falou: "Eu queria falar com a dona Lisete". Eu falei: "Está falando". Ele falou: "Como é que a senhora ousa?", e fez um discursinho contra meu parecer. E eu disse: "Meu senhor, é o seguinte, o processo está com o Dr. José Bonifácio, ele fica no $9^{a}$ andar, o senhor procure por ele". A Secretaria funcionava no Largo do Arouche. "Ele está lá". Petulante a gente era: "E eu me admiro muito. O senhor é um general, o senhor devia ter vergonha de ter vindo aqui fazer isso, porque é uma malandragem o que o senhor está pedindo". E ele falou: "A senhora não ficará mais aqui". Eu falei: "Perfeitamente". Eu sei que ele desceu para falar com o José Bonifácio. O José Bonifácio ficava bastante na Secretaria também, e ele estava lá. Ele leu o meu parecer e mandou o general embora. Lembre-se que o José Bonifácio podia pôr general para fora, porque ele era protegido, era dono da Usina Ester, uma das maiores produtoras de açúcar e álcool do País e, portanto, podia pôr general três estrelas para fora. E, na segunda-feira, ele me chamou. Falou: "Lisete, estou te nomeando para outro cargo em comissão". Bom, eu pensei que era uma brincadeira, porque ele ia falar: "Estou te dispensando, vai ficar em comissão na sua casa". E aí, ele falou: "Olha, esteve aqui o general fulano de tal". E ele falou: "Precisa ter muita coragem para escrever o que você escreveu e fundamentou. Eu confesso, eu telefonei, eu não podia acreditar totalmente em você porque se tratava de um general. Telefonei lá para o MEC, perguntei se tinha esse processo que você citou, e tinha, surpreendentemente tinha. Então, parabéns, obrigado".

E isso me deu uma sobrevida. Eu fiquei na secretaria e nesse tempo todo teve várias questões, porque eu cuidava também do dinheiro. Aí ele pedia, às vezes, para verificar as contas da CONESP, que era a Companhia de Construções Escolares do Estado de São 
Paulo, em que ele tinha colocado um amigo. E essas coisas todas, quer dizer, eu participei de várias situações delicadas em termos de construção de escola, custo de construção de escola, como é que foram feitas as prestações de contas e eu fui aprendendo. Quer dizer, em termos de orçamento eu fui aprendendo várias coisas. Como é que se mente, mas como é que se faz direito também, boas sugestões que eram dadas, boas reformas que eram feitas, aproveitamento efetivo de terrenos etc. $E$ eu fiquei sempre nessa área em que eles acreditavam que o comunista não ia ler o Manifesto Comunista antes de começar o trabalho. Mas, enfim, foi interessante e eu tive até essa situação delicada de ter que falar para o José Bonifácio, foi a última vez que a gente conversou: "Doutor Bonifácio, tem rolo aqui nas notas". Doutor Bonifácio, não o chamava de professor. Professor era o José Mário Azanha. professor é o Paulo Freire e não ele. E fiquei muito constrangida, mas disse: "Olha, envolve o seu amigo". Nesse dia, eu acho que se ele pudesse me pôr para fora, ele tinha posto, mas ele se controlou e mandou chamar o amigo dele. E foi a nossa última conversa por conta disso. Quando ele chegou lá, eu abri os dados. Nem a Mariinha Tamazo sabia dos detalhes. É claro que ela ainda falou para mim: "Lisete, você acha que é necessário você falar isso para o doutor Bonifácio?". E eu falei: "Mariinha, não tem como. Um cargo em comissão quer dizer um cargo de confiança. Então, se eu não fizer isso, eu mesma perco a minha dignidade, certo? Ele faz o que ele quiser com a informação...".

Fineduca: Você citou a CONESP (Companhia das Construções Escolares do Estado de São Paulo). A gente pode dizer que a rede estadual nessa época tinha, de fato, uma certa política de planejamento e que depois foi sendo abandonada?

De fato, o meu tema é que simplesmente os anos vão passando e as pessoas não falam mais em planejamento. Você veja só, mesmo agora - essa é uma discussão que a gente tem que fazer - na questão do FUNDEB (Fundo de Manutenção e Desenvolvimento da Educação Básica), não tem nenhuma exigência de que tenha um plano de construções para que, de fato, as crianças caibam em período integral, como seria, em tese, o direito da maioria, se é que você quer caminhar nessa direção. Nem o estado de São Paulo, está certo? Você tinha plantas padrão. Eu também não gosto muito de planta padrão. Eram três. Não gosto muito de planta padrão, porque eram prédios de seis, 12 e 18 salas. Terreno pequeno, médio e grande. Agora, existia uma questão. Depois da Operação Escola, em que o dado estatístico existia, o dado tinha que servir para alguma coisa. Não adianta levantar: "Tenho 2 milhões de alunos", sim e onde estão os 2 milhões de alunos? Como estamos vendo agora: "Vai fechar o noturno da única escola que funciona à noite no bairro tal", que é o que o governo Dória ${ }^{12}$ está fazendo aqui em São Paulo. Não tem nenhum documento nas regionais - ou pelo menos que seja conhecido por nós - em que esteja lá uma bola vermelha dizendo: "Não pode fechar esse aqui, porque é o único lugar para atendimento dos meninos e meninas". Então, eu confesso para vocês, pouco ou mal, o plano era obrigatório.

Você tinha um plano quadrienal, porque você tinha que apresentar no orçamento plurianual um plano plurianual de construções escolares. Também existia um plano de avaliação do que havia sido realizado. Até porque nós estávamos vivendo aquela situação dos quatro períodos de funcionamento das escolas. $\mathrm{E}$, quatro períodos não pode continuar funcionando, onde que

12 João Agripino da Costa Doria Junior, governador do estado de São Paulo, gestão 2019-2022. 
vai construir? É verdade que o estado de São Paulo sempre foi muito independente, no mau sentido. Ele nunca consultou as prefeituras, nem a prefeitura de São Paulo. Então, o processo de municipalização aqui também foi tudo mais ou menos, entende? O que os secretários combinavam, que também não sabiam nada, valia. Você vê que tem até hoje escola uma em frente à outra, uma do estado, outra da prefeitura, o que é um absurdo. A menos que você tivesse negociado: "Essa aqui não cabe, de fato, tem muita gente". Enfim, que fosse fruto de negociação. Mas o estado tinha um plano que ele seguia, com uma razoável responsabilidade no sentido de construção; preço já é outro campo. Mas eu digo, em termos de definir, por exemplo, se não está em cima do rio, se não é muito próximo. Por exemplo, eu vi engenheiro e arquiteto viajando para o Vale da Paraíba, para saber exatamente onde que é a escola, você entende? Por exemplo, Conchas estava lá anotado: "Não cabe outra escola, porque é uma cidade em desaparecimento". Então, tem 10 mil habitantes, hoje tem 10 mil, imagina. Quer dizer, é em desaparecimento. Então, o que eu quero dizer é o seguinte, que havia um trabalho técnico. Estou lembrando da arquiteta Mayumi Watanabe Lima aqui como uma referência.

A Mayumi foi mais do que a CONESP, ela passou a introduzir uma outra variável que começou a crescer, mas que não deu tempo em função da sua morte. Ela defendia que quem define a planta é o projeto pedagógico. Porque a Mayumi talvez tenha sido a primeira arquiteta que perguntou: "E o que é que vocês, professores, querem fazer aqui dentro?". Nossas homenagens a ela, porque realmente foi um grande avanço. A Mayumi uma vez esteve na minha sala de aula e pegou os alunos e saímos caminhando à noite. Ela mostrou para os alunos: "Vocês estudam em um privilégio que é esse espaço da USP. Quantas vezes vocês caminharam por onde nós estamos caminhando?". E nós pudemos ver que, nem o clube, nem o centro esportivo, que é ali do lado da atual Faculdade de Educação, era visitado por eles. Porque eram alunos que trabalhavam, eram mais velhos e, portanto, eles não faziam da Universidade um locus privilegiado de estar, de vivenciar.

Então, eu estranho mesmo a prefeitura de São Paulo. Quer dizer, você pega hoje, com toda a estrutura que tem... na gestão da Luiza Erundina a gente tentou fazer esse mapeamento de construções, construímos, pedimos prédio também para o estado, que cedeu para a gente. Fui lá conversar com o governador Quércia ${ }^{13}$, de campineiro para campineira, para pedir uns prédios, porque nós tínhamos assumido mais crianças. E, efetivamente, os prédios vieram para nós. Prédios que estavam prontos e de acordo com o padrão deles. Mas você veja que até os anos 90 havia o planejamento de prédios escolares na cidade de São Paulo construídos pelo estado. Hoje não tem nenhum, que eu saiba. Há muitos anos que não tem previsão de construção de prédios pelo estado.

Fineduca: Lisete, comenta um pouco agora sobre sua experiência na Secretaria de Educação de São Paulo, com o Paulo Freire, e, posteriormente, em Diadema.

Antes de comentar essas minhas experiências, eu só vou dizer que eu acabei saindo da secretaria porque fui absolvida no meu processo político. Eu prestei um concurso público e assumi um cargo de direção de escola estadual no Jaraguá, onde fui diretora por um ano. E, depois, fui para a Secretaria de Educação do município, junto com o Paulo Freire.

13 Orestes Quércia, governador de São Paulo de 1983 a 1986. 
Bom, gestão Paulo Freire. Vocês perguntaram que coisas eu destacaria. Eu destacaria, talvez, três coisas que sempre vão virar cinco ou seis, porque tem muita coisa que eu gostei bastante. Lembrando, eu não vou detalhar aqui, mas trabalhei na gestão Mário Covas, quando ele era um homem democrático, foi prefeito. Trabalhei na gestão da Guiomar ${ }^{14}$, na Secretaria Municipal de Educação (1983/85), na época que ela era comunista. E foi interessante, aprendi coisas também. Paulo Freire, no dia $1^{\circ}$ de janeiro, não foi em outro dia, Paulo Freire publicou no D.O.M. (Diário Oficial) a revogação do ato de Jânio Quadros ${ }^{15}$ em relação ao regimento comum das escolas, que era um documento que tinha sido muito discutido pela rede e que era o mais avançado que havia de discussão da rede. Então, o Paulo Freire fez questão de retomar o regimento das escolas e, segundo, as propostas curriculares - por isso que eu estou dizendo que era outra Guiomar e outra Rose Neubauer também - que haviam sido feitas mediante consulta à rede. Algo que havia sido objeto proibido durante a gestão Jânio Quadros, que mandou queimá-las e vender a peso de paina as propostas curriculares, Paulo Freire retomou-as.

Isso foi uma mensagem que eu considero muito importante em política educacional, que é a seguinte: "O mundo não começa quando você ganhou a eleição. Queridos partidos e dirigentes, o mundo existe antes de você, teve resistência, teve coletivo, teve construção conjunta. Então, que tal respeitar aquilo que a rede já produziu?". Considero que isso era uma atitude que define um pouco a posição do Paulo Freire, que é o respeito pelo trabalho alheio.

Segundo, vou dizer aqui, porque eu acho que é uma questão que a mim é muito cara, que assim que a gente assumiu, lembre-se que a Constituição tinha sido aprovada dia 5 de outubro, estávamos em fase desesperada de construção da Constituição Estadual e todos nós participávamos, via movimento, também disso. E, nesse momento, a Constituição Federal tinha estabelecido o concurso público como forma obrigatória de ingresso. Concurso público de títulos e provas. No dia 10 de janeiro, mais ou menos, a Luiza Erundina recebeu do Tribunal de Contas uma carta com cópia a todos os secretários perguntando quando seriam realizados os concursos, porque eram mais de 90 mil funcionários que estavam contratados.

O Jânio não fez nenhum concurso. Na carta constitucional de São Paulo já tinha um dispositivo que dizia que a prefeitura contrataria órgão especializado para fazer o concurso, que era uma garantia de que não houvesse uma ação entre amigos. E, portanto, no caso, a Aldaíza Sposati, que era coordenadora das regionais, contratou a Fundação Carlos Chagas. As providências foram tomadas e definiu-se que era uma prova escrita e, depois, contava títulos e a prova escrita era para todos, inclusive para os chamados funcionários de nível básico, que eram jardineiros, vidraceiros, cozinheiras, todo o apoio de todas as secretarias.

O Paulo Freire - vocês sabem disso - gostava de ir para as escolas. Ele deixava os processos com a gente, aliás, o que me cabia, e saía para visitar as escolas. E, nessas idas, ele foi encontrando com as pessoas, que diziam: "Professor, as coisas mudaram de nome. Predicado hoje chama 'complemento nominal'. Eu não vou passar no concurso". E aí, nós resolvemos fazer uma coisa. A gente subia no elevador, o ascensorista do nosso prédio queria prestar o concurso e ele toda vez falava: "Por que é que tem raiz quadrada?". "Tem [raiz] triangular, tem...?". E aí, nós discutimos e o Paulo Freire foi ficando sensibilizado. Eu estou

14 Guiomar Namo de Nello foi Secretaria Municipal de Educação de São Paulo no período de 1982 a 1985, na gestão do prefeito Mário Covas.

15 Jânio da Silva Quadros foi prefeito de São Paulo de 1986 a 1989. 
falando isso porque, em uma vez que ele foi com a Nita Freire, as mulheres de uma creche se reuniram, pegaram a Nita lá no cantinho e a Nita saiu chorando de lá, porque eram histórias dramáticas. E aí, nós fizemos. Coube a mim fazer um parecer no qual o Paulo Freire propunha que se mudasse a forma do concurso. Bom, eu fiz uma parte, porque eu podia fazer isso de ir na reunião lá da Secretaria de Administração e dizer: "Olha, o professor quer fazer uma forma diferente, ele acha que é injusto, porque quem está no trabalho e até os estáveis são inscritos obrigatoriamente no concurso. Então, eles podem perder o cargo". E aí, eu falei para ele: "Professor, você tem que ir lá e fazer a mágica. O mito tem que entrar lá na reunião". E o Paulo Freire fazia isso com muita tranquilidade, por isso que eu devo a ele ainda um relato sobre a experiência, eu escrevi um pouco, mas ainda é pouco. Eu tinha me comprometido de escrever um livro sobre gestão educacional, que era exatamente porque o Paulo Freire foi um dirigente muito competente, na minha opinião. E ele foi lá para defender uma lógica que é perfeitamente viável, se nós defendíamos - e defendíamos - que o candidato à presidência da república pudesse ter só o quarto ano primário, como é que nós poderíamos exigir que o nosso jardineiro soubesse o que é raiz quadrada? E ele pediu uma inversão na sistemática, que era exatamente fazer o exame prático e, depois, o teórico seria classificatório, mas o que aprovaria seria o exame prático. Só o Paulo Freire para conseguir isso. A Fundação ficou com os pelos em pé, porque era uma maluquice, acho que eram 118 cargos, porque ia de médico, passando por professora, a todos os cargos. E no nível básico era onde estava a maior variação.

Foi uma experiência incrível, porque quem cozinha vai cozinhar, quem varre, vai varrer, quem põe vidro, vai vidraçar, quem está no jardim, vai jardinar. A gente chamou o SENAI - nós não sabíamos nada disso - e o SENAC, que tinham formas de medir o desempenho nessas profissões. Eu aprendi porque participei de alguns, virei membro da comissão também do concurso. A gente montou um levantamento de opinião, na época, para entrevistar as pessoas que saíam do concurso. E todo mundo falava: "Gostei do concurso porque se eu for reprovado eu serei naquilo que eu deveria saber fazer!". Nós chamamos os diretores de escola, fosse de direita, esquerda, cima, baixo porque eu acho que tem uma responsabilidade profissional que está acima do partidário. As pessoas não são tão partidárias assim, nem sabem o que é partido, nem levam a sério partido. E falamos para eles: "Olha, vocês vão ser os avaliadores, está certo? Não necessariamente do seu funcionário, porque aí não pode, compromete, mas vocês vão receber outros, mas são vocês que vão fazer a avaliação". E eles toparam. Eu acho até que eles nem acreditavam que a gente ia fazer isso, mas eles toparam e fizemos.

Implantamos uma estratégia de guerra, porque, por exemplo, o marceneiro ia consertar carteira. Já a produção das cozinheiras nós íamos doar para asilos e outros lugares, distribuição de sopa à noite, fosse o que fosse que caísse para elas lá, que ia de lasanha a sopa, foi uma coisa muito bonita. Eu tenho imenso respeito, porque precisa muita coragem para assumir que ali tem vida de pessoas, havia pessoas que trabalhavam há 15 anos na prefeitura. Elas podiam ter sido nomeadas pelo amigo delas, mas depois de 15 anos, se as pessoas se mantiveram, elas até já tinham aprendido a fazer o que elas tinham que fazer, porque vocês sabem que diretor pega no pé, principalmente com relação a funcionário que não trabalha. Ainda mais, se ele pode dispensar, ele dispensa, não é tão bonzinho assim. Então, eu considero que esse ato do Paulo Freire foi uma coisa muito interessante. 
A outra coisa que ele topou fazer, que era uma injustiça legal, em relação aos professores que ocupavam cargo em comissão e, comissionados, eles não tinham direito à estabilidade. Era uma sacanagem da prefeitura. Porque eles se inscreviam, tinham uma classificação por títulos, não era cargo em comissão, era qualquer outra coisa, era um cargo como qualquer outro. Era nomeado por ordem de classificação, portanto, inclusive com um aparato público, você podia reclamar da sua classificação e tudo, como é que pode dizer que é em comissão? $\mathrm{E}$ foi muito interessante, porque foi uma briga entre o nosso secretário de justiça e o secretário de governo, José Eduardo Cardoso e o Dalmo Dallari, porque para o José Eduardo era impossível uma coisa dessas. E o Dallari falava: "Essa é a cabecinha de promotor, cabecinha de advogado é outra. Cabeça de advogado defende a injustiça; já vocês têm que defender o Estado, o status quo". Foi muito interessante, até chegar a um ponto que o José Eduardo concordou de fazer um parecer meio em cima do muro, para não ter um processo que tivesse também uma posição antagônica entre dois secretários do governo. E, portanto, levou acho que uns três anos, dois anos e meio. Lembro que era o Hélio Bicudo no início, depois foi o Dallari. E, de fato, conseguimos corrigir, os professores foram declarados estáveis. Muitos deles estavam passando no concurso e, portanto, nem se interessaram por se tornar estável, mas essa injustiça foi corrigida.

Uma outra coisa que eu acho que o Paulo Freire fez, que era dele, é que ele prometeu e cumpriu. Ele foi um secretário muito coerente. E eu tenho o prazer de ter trabalhado com ele em relação a esse aspecto do caráter dele, porque ele disse: "Eu não publicarei nenhum ato legal, seja portaria, deliberação, o que for, que não tiver sido discutido previamente com a rede". E nenhum ato nós publicamos. Haja reunião, nenhum ato se publicou que não tivesse isso.

Eu acho que os outros aspectos de sua atuação já são mais conhecidos. Ele tinha também uma grande preocupação com o estatuto do magistério. Foi o primeiro estatuto, mas o Paulo Freire era muito preocupado com as condições de vida dos professores. Eu confesso que eu até defendi que a JTI (Jornada de Tempo Integral) tivesse 40 horas, que fosse a mesma fórmula que é na escola de aplicação da USP, seriam 20 horas com aluno, 20 horas para trabalhos extraclasse, 10 obrigatórios na escola e $10 \mathrm{em}$ local de livre escolha, para o professor corrigir prova em casa etc. Mas acabou saindo 30. Por quê? Porque se saísse 40, nós tínhamos professores efetivos em dois cargos e eles seriam eliminados automaticamente. Porque não adianta criar a coisa e depois falar: "Você ganha a mesma coisa que você ganhava antes". Mas nós conseguimos isso. Primeiro, que a JTI significasse $100 \%$ de aumento. Foi a primeira vez e única que os professores tiveram $100 \%$ de aumento no seu salário. Então, eu acho que essa discussão sobre as condições de trabalho foi um avanço, e não é só a questão de financiamento, a questão do limite de 30 alunos por turma também se tentou obedecer.

Nós tínhamos pré-escolas que tinham um maior número de alunos por turma, mas ele estava esperando construir escola para diminuir esse número. Outra coisa foi a experiência de transferirmos para a escola um dinheiro para as escolas que apresentassem projetos. No caso, era sobre a via da interdisciplinaridade. Muita bobagem apareceu. Eu costumo contar uma, porque foi muito interessante: nós fomos a uma escola, chegamos lá e perguntamos: "Bom, qual é o tema gerador que vocês escolheram aqui?" e a diretora falou: "O café-da- 
Entrevista com Lisete Regina Gomes Arelaro

manhã". Nós achamos: "Bom, ok". Paulo Freire nunca ria assim: "Hahaha" de qualquer bobagem que ele ouvisse na rede.

Ele primeiro ouvia até o final, ele era um grande ouvinte, para depois falar alguma coisa. E foi muito interessante, porque a diretora falou: "Olha, o nosso principal problema aqui era a relação entre as pessoas e isso estava tão ruim que estava entre os alunos e entre alunos e professores. E aí, nós resolvemos fazer o café-da-manhã. A gente começa 15 minutos antes e invade 15 minutos do horário e toma um café juntos, professores e alunos. Bom, não tem nada de tema gerador nem de interdisciplinaridade, mas era superinteressante, porque a escola - e nós pudemos acompanhar - foi melhorando dia a dia. Primeiro, porque tinha aquela história que o almoço era às 11 horas e essas crianças chegavam com fome. Portanto, o caféda-manhã serviu muito bem para as crianças entrarem para a aula com a barriguinha cheia. E eles definiram lá, fizeram uma divisão muito interessante, tinha bolo, tinha pão com manteiga, tinha uma que fazia uma geleia. Então, tinha variações em torno do tema e sempre era escalado um professor que levava uma coisa diferente. Mas a gente transferiu o dinheiro para a escola e isso foi apostando no sentido de que a escola é séria, está procurando melhorar a sua qualidade e a qualidade tem várias formas possíveis.

Então, teve jornais, elaboração de jornais, teve estímulo ao teatro e teve rádios. Lembre-se que nessa época estamos começando essa discussão de comunicação e cultura popular e as escolas tinham sede dessa história de rádio. Estou lembrando aqui da Célia Giglio, que já tinha uma rádio mantida na escola pelos alunos. E o que Paulo Freire fez foi estimular muitos grêmios. E, para ele, o grêmio começava do primeiro ano do ensino fundamental em diante, pois a criança sabe o que quer. As escolas de ensino fundamental passaram a ter grêmio e, obviamente, a criação de um conselho de escola deliberativo, e lamento muito a situação que nós estamos hoje, porque eu ainda encontro alguns diretores, algumas diretoras que eram daquele tempo e essas diretoras faziam churrasco, faziam franguinho assado, faziam feijoada, as escolas ficavam abertas no final de semana. Outra coisa, os diretores não eram obrigados a ficar lá, bastava um pai de aluno e um professor, um pai de aluno e um aluno maior para ser responsável. Mas o diretor não consegue, ele abre a escola 'dele' - como ele fala, ele vai lá, entende? Então, muitas coisas interessantes aconteceram e a escola ficou mais da comunidade.

Isso era um empenho do Paulo Freire. Ele ia em reunião, tinha almoço dos professores lá não sei onde, ele ia, se encontrava com 12 professores. Então, ele facilitava também isso. Ele saía escondido para ir nesses lugares, para não causar ciúmes para os outros, não queria que noticiassem que ele ia, porque senão virava atividade oficial. Então, eu vejo que a relação com a comunidade foi alguma coisa que foi feita de forma muito espontânea. É claro, eu não vou diminuir aqui para vocês o momento que a gente estava vivendo, o momento histórico que nós estávamos vivendo. Claro, tinha um processo de "redemocratização"; tinha a vontade dos direitos para todos, os professores também estavam sendo respeitados, tinha um ombro, sabe? Professor ia mais alegre. Eu acho que trabalhar em um lugar que a gente goste é fundamental, a gente ir trabalhar um pouco satisfeito é condição também de qualidade de ensino. Eu me irrito menos com o meu aluno, não tem dúvida nenhuma.

E pelo fato de o Paulo Freire sempre dizer que ele não estava obrigando, ele estava sugerindo e sempre dizer em toda ocasião: "Se vocês concordam comigo, não me repitam, me reinventem". Olha, não foi em uma ou duas escolas que nós fomos e que os professores 
estavam usando cartilha. Quando a gente chegava, não vou mentir para vocês, eles colocavam na gaveta e acho que mandavam os molequinhos colocarem na gaveta também. A gente saía, e sabia que ele iria tirar a cartilha, mas ninguém era punido porque usava a cartilha. Ele dizia que outras formas de trabalhar eram melhores, mais gostosas, mais estimulantes, mais significativas, mas nunca foi proibido trabalhar com o tal do livro padrão. Então essa foi uma gestão que eu considero vitoriosa.

\section{Fineduca: Sobre a experiência em Diadema.}

Já em Diadema, eu tinha um privilégio, que era o seguinte, eu tinha educação, cultura, esporte e lazer em uma secretaria só. Eu confesso para vocês que Diadema também me divide, eu brinco: "Eu sou antes de Alagoas, depois de Alagoas e sou antes de Diadema, depois de Diadema". Por quê? Porque Diadema era um bairro de São Paulo. Diadema tinha 350 mil pessoas, era um bairro da Zona Leste, que tem 3 milhões e meio de pessoas. E aí, foi muito interessante, porque eu vi como a gente é sectário em relação à nossa área. A cultura e o esporte reclamavam da gente, mas nada como você estar com eles e sentar para discutir um orçamento, viabilizar atividades, trabalhar com as mesmas mães que são da escola na área de esporte, em especial no projeto Mulheres em movimento, que era permitir a uma mulher pobre, casada com um machista, sair de casa para fazer ginástica, cuidar de si; isso é altamente revolucionário. Isso muda mais, às vezes, do que participar de um Conselho de Escola. Lá havia também, no Conselho Municipal de Saúde, um processo de formação com mães que era muito interessante. Eu tinha uma especial predileção pelo primeiro prefeito do PT, Gilson Menezes, pela distribuição de terrenos públicos a quem não tinha casa, mas em curto prazo isso virou o terror para os urbanistas.

Eu tive o prazer de ter passado quatro anos lá. Foi difícil também receber o 'passaporte', porque eu era de "fora", mas dizia para eles: "Olha, eu sou muito mais daqui do que vocês. Eu atravesso a rua aqui e estou na cidade de vocês. Eu sou de São Paulo e estou na cidade de vocês". Mas levou um tempo para conseguir ter legitimidade. Eu aprendi muito, porque cultura, esporte, lazer e educação acabaram se encontrando em mim e na cidade.

Vocês sabem que eu assumi no dia $1^{\circ}$ de janeiro de 1993, e a gestão anterior também era petista, mas a gente assumiu sem ter dado nenhum, nem de alunos, nem de escola, nem de nada. E o carnaval foi, para azar nosso, logo em fevereiro. Eu tomei posse dia $1^{\circ}$ à tarde e, no dia 2 de manhã, as escolas de samba estavam embaixo da minha janela - era uma casinha, a secretaria - querendo saber quanto que eu ia dar para eles, como é que ia ser o carnaval etc. Eu não tinha a mínima ideia, eu nem sou propriamente carnavalesca. Eu tive sorte que a Sônia Kruppa era carnavalesca. Então, ela ajudou, vinha com animação, porque eu não tinha nem a animação que precisava. E nós tínhamos que preparar as ruas para isso, precisava de ônibus da prefeitura para pegar os integrantes das escolas de samba, que eu também não sabia disso.

Eu lembro que a gente estava fazendo um edital para viabilizar microfone para as escolas de samba e aí fomos alertados por um servidor da Cultura: "Querida secretária, a senhora sabe o que está escrito nesse seu edital. Pois é. Aqui, se eles comprarem aquele microfoninho da Barbie, passa, porque está escrito 'microfones'. A senhora tem que especificar tudo. E na área, nessa área de som, mais ainda, porque o coordenador da escola, tem que apitar lá 
Entrevista com Lisete Regina Gomes Arelaro

adiante, e o som tem que vir até o final da avenida. São microfones especiais, são caixas de som especiais, etc.".

Então, só para vocês saberem, a dificuldade começou aí, não começou na educação. E aí nós tivemos possibilidade de fazer encontros, que fazia também muito tempo que os professores de lá não se encontravam, encontros anuais para contar a sua experiência, troca de experiência, conversar com o seu colega. Pudemos levar o Paulo Freire nos encontros, que foi também um privilégio desde o primeiro ano de gestão, em 1995 levamos o Paulo Freire e o Paulo Renato de Sousa, ministro do $1^{\circ}$ governo FHC, para que ele aprendesse com Freire como era um programa de alfabetização de jovens e adultos, vocês acreditam?

Em Diadema eu tive um embate diário com a Rose Neubauer, Secretária Estadual de Educação. Nós fizemos muita coisa lá bonita, mas a coisa principal foi ser contra a municipalização. Porque nós tínhamos uma situação muito delicada, pois, no ensino fundamental, as crianças estavam matriculadas nas escolas estaduais, mas nós tínhamos mais de 12 mil crianças que precisavam de creche e pré-escola que não tinham para onde ir, então não tinha cabimento a gente assumir as crianças que frequentavam a rede estadual, como buscava impor a Rose. A discussão era: "O que é que eu vou fazer para que todas as crianças sejam atendidas?". A Rose Neubauer queria quebrar a gente nisso e, obviamente, ia conversar com um promotor local frequentemente. Ela falou: "tem uma escola [estadual] que está caindo". Eu disse: "Ok, a gente aluga um prédio, cede, fica, dá um jeito até de dividir enquanto tiver a reforma do prédio, mas nós não vamos partir para esse projeto de municipalização. Nós queremos consultar as pessoas sobre ele". Não cedemos e resistimos à proposta de municipalização do estado.

E a gente teve várias coisas boas. Primeiro, a gente teve lá a Zilma de Moraes, que ouviu todas as nossas professoras de creche e fez uma proposta coletiva muito bonita. Outro aspecto interessante, a gente tinha cozinheiras lá, essa ideia de que todos somos educadores e educadoras é alguma coisa que era muito forte também em Diadema. $E$ a atuação das cozinheiras era muito bonita, porque, por exemplo, para estimular as crianças a comer legumes, elas faziam pratos enfeitados, em formato de carinha. Em respeito às crianças negras faziam um hambúrguer que tinha um cabelinho enrolado, que podia ser de gema ralada. E eram as crianças que faziam isso na hora de comer, uma ia fazer para a outra comer, entendem? E obviamente que a gente conseguiu comprar comida natural e saudável para as crianças, e eu diria que a escola era uma escola gostosa.

Nós tivemos um problema sério lá que envolveu a eleição de diretores. O que acontecia no $A B C$ era o seguinte, eu deixo escolher diretor se ele for meu amigo. Eu estou falando isso porque eu tive amigos que fizeram isso em outras prefeituras do PT do ABC. E eu sou contra isso. O povo elegeu? Paciência, mas ele vai tomar posse. Então, eu mantive as diretoras que tinham sido eleitas. E não tinha problema nenhum. Elas falavam mal de mim? Provavelmente, certamente, mas, em termos profissionais, elas eram muito boas diretoras. E eu estranhava um pouco, porque aqui em São Paulo até era mais dividido, elas faziam questão de coordenar pedagogicamente o que acontecia na escola. Não era assim, que administrativo é uma coisa, pedagógico é outra.

É verdade que não tinha orientador pedagógico nas escolas, eram elas que cumpriam essa função. A gente até criou depois, a pedido delas, mas isso não quis dizer que elas dividissem 
Entrevista com Lisete Regina Gomes Arelaro

o trabalho, nem estava escrito isso no estatuto que a gente propôs, e que foi aprovado na gestão seguinte do Gilson Menezes, que voltou a ser prefeito.

Agora, Diadema é Diadema. Então, por exemplo, eu me lembro de ter participado do grande debate, quando o Gilson Menezes assumiu, nos anos 1983, quando começou essa discussão com as primeiras municipalizações. Eles eram todos municipalistas, se deixasse municipalizavam tudo. E eu dizia para eles: "Olha, gente, quando sair o FUNDEF vocês vão ver o perigo". Estava nas discussões do FUNDEF, em 1996, último ano da minha primeira gestão lá em Diadema. Em 1996, a gente conseguiu que o conselho do Grande ABC assinasse uma carta alertando que a pré-escola ficaria de fora se fosse aprovado o FUNDEF. Foi a única região do Brasil que conseguiu assinatura dos sete municípios em defesa das nossas crianças. Também havia uma relação diferente de solidariedade no $A B C$, que, mesmo sendo de partidos diferentes, ajudava.

E eu confesso para vocês que eu fui aprendendo também, porque eu não era da área da Cultura. Por exemplo, tinha rádio que telefonava e falava: "Professora, podemos ir aí no sábado? Precisa só armar um palanque lá na praça". Claro que a primeira vez eu disse sim, até descobrir que a rádio era, por exemplo, a Rádio Atual, que tinha 2 milhões de ouvintes. $O$ Elmir de Almeida era o nosso diretor de cultura. Eu acho que ele ficava rezando, eu nem sei se ele sabia rezar, mas rezava, porque ficava aquele monte de gente. Porque Diadema, vocês têm que lembrar, como são 33 quilômetros quadrados, as pessoas moram empilhadas. Portanto, você assobia e aparecem 153 pessoas para saber o que você quer. Então, sempre tinha gente, para tudo tinha gente. Não havia conselho que não tivesse participação. Não tinha falta de quórum, mas excesso de quórum, sempre.

Então nós chegamos a fazer na área da Cultura muitas atividades. Você veja que Diadema tinha uma peculiaridade, que eu vou comparar aqui com Campinas. Diadema, com 33 quilômetros quadrados, tinha 10 centros culturais. Um em cada bairro. Campinas tinha apenas um centro cultural, no centro da cidade, onde o acesso da periferia era zero. Então recebemos vários artistas. Lembro-me que, quando cheguei, contratamos até uma mocinha chamada... Daniela Mercury, que recebeu 5 mil reais para cantar em Diadema. Uma mocinha de voz afinada, uma baiana de voz afinada. E vários artistas conhecidos hoje passaram por Diadema. Caetano Veloso, Rita Lee, Jorge Ben Jor, Gil, Chico Cesar, Inezita Barroso.

O fato de ser uma prefeitura do PT era também um chamariz, porque a gente valorizava a cultura e eles iam por valores bem simbólicos. Havia atividade todo final de semana e, depois, durante toda a semana. Esse é um mérito do Elmir, a ideia de que usufruir cultura era um direito de todos. O nosso prefeito era um pianista, e ele convidou dois pianistas famosos, que foram seus professores, para trabalhar com flauta com as crianças e jovens, mas não para ensinar flauta. Eles tiveram um contato com os pais para dizer que se tratava de iniciação musical e que eles tinham que aprender todos os ritmos e todos os instrumentos. E eles acabaram ficando em Diadema por mais tempo, praticamente durante toda a gestão, e se apresentavam com 110 crianças, por exemplo, porque, para nós ou era com todos, ou não era com nenhum. Então, não trabalhar só com os melhores. Até podia ter, mas na apresentação tinha que ter todos, porque vai ter um pai ou uma mãe ali esperando: "Meu filho está lá cantando ou tocando ou isso ou aquilo". Nessa gestão do Felipe: Educação, Cultura, Esporte e Lazer foram prioridade. É muito diferente quando você é secretária de uma área que é considerada prioridade de governo. 
Outra questão, quando eu fui secretária na primeira gestão, não tinha Lei de Responsabilidade Fiscal, não tinha sido aprovada a Emenda Constitucional no. 19/1998, portanto era muito fácil governar - sei que é estranho falar isso -, mas Diadema, que era uma cidade de pobres, não era pobre em termos de orçamento. Então, a gente fez muita coisa. Em relação à formação de professores, isso foi magnífico, ter os encontros, ter o Paulo Freire lá e quem mais eles quisessem e eles queriam muitas pessoas e todas as pessoas foram e aceitavam, porque esse trabalho de relação eu sabia fazer, porque tinham sido meus colegas, meus amigos ou professores, enfim. É fácil para a gente pedir para as pessoas irem onde a gente está. Então em termos de dinheiro era muito mais fácil.

Eu assumi pela segunda vez em 2001, quando estava entrando em vigor a Lei de Responsabilidade Fiscal, ela foi aprovada em 2000, entrando em vigor no ano seguinte. E Diadema tem uma situação delicada, pois ela fica entre Santo André e São Bernardo, que são as cidades que melhor pagavam o funcionalismo público, ou que pagavam na época. Então, nós não tínhamos muita escolha. Por exemplo, um médico em Diadema ganhava o mesmo que pagava a prefeitura de São Paulo, porque se não pagasse o mesmo valor, ele não ia. Então, não tem jeito, ou paga a mesma coisa ou você não tem o funcionário, dedicado, trabalhando. Quando nós assumimos, em 2001, no dia 12 de janeiro, mais ou menos, o Felipe recebeu a primeira carta do Tribunal de Contas do Estado, que dizia: "Parabéns, prefeito. Querido prefeito, quantos funcionários o senhor vai dispensar? Porque vocês gastam $80,5 \%$ do orçamento em pagamento de pessoal". E não era brincadeira, porque a forma de eles garantirem o cumprimento dessa medida era deixando de repassar o ICMS. E o ICMS era a principal fonte de recursos.

A gente brincava: "Alô, alô, funcionários públicos, peçam aumento na quinta-feira, porque quarta-feira é o dia que tem o repasse do ICMS para os municípios. Então, na quinta-feira o prefeito está sempre alegre, o secretário de finanças também. Sexta ele já está preocupado, mas na quinta é o dia que ele ainda tem um sorriso". Então, nós começamos o ano de um jeito muito difícil, pois trabalhar com a Lei de Responsabilidade Fiscal e o Tribunal de Contas no pescoço da gente não foi fácil. Para eu não dispensar as cozinheiras e auxiliares das escolas, foi dificílimo. Porque vocês sabem, a tendência é fazer um corte linear nas despesas; reúne o secretariado, o secretário da Fazenda simplesmente fala: "Corta por inteiro". Aí nós falamos: "Olha, não pode, porque esses homens e mulheres aqui têm história. Têm um passado, têm um presente e têm um futuro. Não tem muito jeito aqui". Mesmo Diadema sendo uma cidade industrial. Agora, nós tínhamos uma coisa que era grave, Diadema tinha $37 \%$ de mulheres como cabeça de família. Era uma das poucas cidades que tinha essa situação. Então havia uma grande demanda por parte das mulheres de ingresso no mercado de trabalho. $\mathrm{E}$ aonde ia pôr as crianças? $\mathrm{E}$ as escolas têm que ter um mínimo de condição. $\mathrm{E}$ não adiantava simplesmente falar que as escolas fechavam às $18 \mathrm{~h}$, porque muitas mães e pais estavam vindo de São Paulo, São Bernardo etc.

Então, a situação era muito difícil. E eu saí no segundo ano de governo, porque resolvi ser candidata a deputada estadual. Mas eu quero dizer que estabelecer na Lei de Responsabilidade Fiscal o tal dos $60 \%$ de limite com pessoal, com $54 \%$ para o Executivo, é um absurdo. É um absurdo até hoje, porque o que falta nos municípios é atendimento na área de políticas sociais e essas áreas demandam gente. Construir um centro cultural, eu construo até em 15 dias, ainda mais hoje que é tudo placa. Vocês viram o caso hoje dos hospitais de emergência. O problema 
Entrevista com Lisete Regina Gomes Arelaro

é manter, como nós estamos vendo aí que não tem médico para trabalhar. O ser humano é que dá vida para as políticas públicas e é deles que nós precisamos.

Então, o que foi acontecendo? Como os governos não iam conseguir manter os limites da LRF, o que eles fizeram? As secretarias da Fazenda deram um jeito, através de uma resolução que é ilegal, mas que é a que vige, na verdade, que estabelece: se você terceiriza, não onera a Lei de Responsabilidade Fiscal, o que não é verdade, porque isso não está escrito na lei. A lei é claríssima: "Contratou, onerou", mas a saída foi esse jeitinho. E aí, nós vamos ver uma modificação brutal no Brasil, que é de ponta a ponta do País, da creche à universidade, ao instituto de pesquisa, todos vão ser contratados como terceirizados. $O$ pessoal da limpeza, o pessoal de apoio, os guardas. Nós tínhamos guardas que dormiam na escola, que tinham vínculo com a coisa pública. A escola pública de Diadema tinha uma dignidade, ela era bonita.

Havia arquitetos jovens; eu era a pessoa mais velha do governo e eu tinha 50 anos. Então, eu dava o braço para o vice-prefeito e falava: "Olha, um século de experiência caminha nesses corredores". O resto, tudo era molecada, inclusive o próprio Filippi, que tinha 34 anos. Então, os arquitetos eram muito jovens e muito criativos. Tanto assim que eles iam mostrar um terreno para mim e eles falavam: "Lisete, olha que legal esse terreno". Eu olhava e falava: "Bom, isso aqui é um buraco". E dali nascia uma escola superbonita que eles tinham feito consultando as pessoas. Diadema tinha isso de muito bonito. Consultavam as crianças, as crianças escolhiam cores e as crianças escolhiam qual era a altura da maçaneta da porta que elas alcançavam. E as cozinheiras e limpadoras escolhiam onde iam ficar os interruptores, que é uma coisa gravíssima. Onde liga a geladeira, a secadora, o fogão, seja lá o aparelho que for, a batedeira para elas trabalharem. Porque, em geral, quando você consulta quem faz, é tudo ao contrário do que os engenheiros colocaram na planta. Então, era um trabalho muito bonito que Diadema fazia.

Fineduca: Lisete, antes de entrarmos na discussão de fundos, eu gostaria que você expusesse sua visão sobre a questão dos repasses de recursos financeiros para as escolas.

Aqui em São Paulo, na gestão Paulo Freire, nós tentamos fazer isso, como já disse. O dinheiro era repassado para as escolas que tinham um projeto, portanto, que tinham passado por alguma avaliação. Muitos companheiros que hoje defendem esse repasse, na época até fizeram abaixo-assinado contra. Eles alegavam que nós queríamos que eles fossem processados, porque eles não tinham estrutura para a prestação de contas. Mas isso não era verdade, tinha estrutura nas regionais, mas eles queriam que se criasse outra estrutura, que tivesse um contador em cada escola. Eu falava para eles: "Olha, gente, contabilidade a gente aprende. Tem a contabilidade oficial e tal, mas a contabilidade que interessa a gente aprende. Agora, tem que ter estímulo do governo para que isso aconteça". Eu estou dizendo isso porque eu faço uma avaliação, hoje, sobre a prefeitura de São Paulo, que eu tenho acompanhado mais de perto, e é um absurdo.

Eu dei cursos nos NAEs (Núcleo de Ação Educativa) na gestão do Haddad, então é bem vivo ainda para mim o medo que as pessoas têm de gastar. Então, guarda o dinheiro e não gasta de medo. Por que medo? Até porque as regionais de educação têm hoje condições de orientar e muito bem, porque boa parte das coisas já está codificada. Mas eles não estimulam. Eles falam: "Olha, cuidado que vai sobrar para você, o processo administrativo é nominal, é você 
Entrevista com Lisete Regina Gomes Arelaro

que vai pagar o pato". Então, por exemplo, eu vejo diretores querendo levar os alunos para passear: "Quero ir para Santos, quero mostrar o mar para as crianças de Itaquera". Não vão. Nós estávamos na Penha e um diretor falou: "Eu quero levar meus alunos ao teatro, mas eu quero levar no domingo". Eu não posso, porque a escola não funciona. Eu falo: "Claro que pode, o conceito de dia útil é uma outra coisa que não tem a ver com a atividade educativa". E aí ensinava como é que fazia. Todos eles falavam: "Puxa, você podia ficar lá na regional?". Eu falo: "Não, se você for processado, eu venho aqui e trago um advogado para te defender". Mas não é tão simples assim como a gente está falando, as pessoas têm medo.

Ser chamado de ladrão é uma coisa que ofende o caráter das pessoas, então, para eu não sofrer represálias, eu não gasto o dinheiro que chega na escola. Lembrando o seguinte, a prefeitura de São Paulo é hoje uma das poucas prefeituras que transfere dinheiro para a escola gastar. A maioria ficou com o projetinho do Fernando Henrique Cardoso, o Programa Dinheiro Direto na Escola (PDDE). É bom que a gente se lembre disso. Ai das mais de 100 mil escolas se não fosse o projetinho PDDE, vou até chamar de "ousadia" o que eles fizeram, mas transformaram o conselho de escola, tiraram sua importância. Claro, isso aconteceu quando transformaram a APM em uma instituição jurídica; para mim era o conselho de escola que tinha que receber os recursos e ter independência. Não conseguimos, mas, da mesma forma eu aproveito esse espaço para dizer que defendo, nos Conselhos Estaduais e Municipais de educação, a existência de uma Câmara de Financiamento da Educação, que ali vai pegar o dinheiro do FUNDEB, mais o restinho que o município tem, mais o dinheirinho atrasado de multa e assim por diante. Se não for em uma comissão só, nunca o município e os educadores vão saber quanto dinheiro de fato tem para gastar em educação. Essa é uma proposta para 2021, já fica aí.

\section{Fineduca: Será que dá para falarmos um pouquinho sobre os fundos?}

Primeiro, sobre a questão de fundos, então eu já disse para vocês que, conforme se discutia o FUNDEF, não era por acaso que eles engavetaram a LDB. Discutia o FUNDEF - que nem menciona a LDB, é importante dizer isso - e, de fato, começaram as discussões públicas em setembro, agosto ou setembro, sendo um ano eleitoral, nós já sabíamos disso. Entrou para o segundo semestre, não se discute outras coisas. Eu lembro que, na época, a gente levantou quantos deputados federais iam ser candidatos a prefeito e o número era significativo. $E$ aí, foi aprovado o FUNDEF. Em setembro de 1996, e o Pará fez aquela história que vocês conhecem de entrar em vigor imediatamente, em 1997; no resto do Brasil os municípios e estados implantaram o FUNDEF em 1998. A partir de 1993, já havia, no governo Itamar Franco, com o professor de administração escolar como ministro, uma comissão com a participação da CNTE, da UNDIME e outros sindicatos, para o estabelecimento do que hoje nós conhecemos como piso nacional salarial do magistério.

\section{Fineduca: O ministro era o Murílio Hingel.}

Isso. E aí teve um fenômeno interessante que eu acho, até porque a discussão sobre fundos é muito mais atual do que se imagina. Eu sempre defendi a vinculação constitucional de recursos para a educação, como é hoje, e por isso não gosto muito de voltar lá em 1932, porque eu acho que a discussão tinha um outro caráter, um outro jeito. Eu já vi gente que não 
Entrevista com Lisete Regina Gomes Arelaro

entende nada de financiamento falar que começou lá. Era uma preocupação, mas em um outro nível. Eu acho que era mais na minha direção de vinculação de recursos do que na de política de fundos. E aí é o seguinte: se começou mesmo a discutir fundos com a CNTE, em 1996, mas tem um movimento que vem também em outra direção, que é o movimento pela educação infantil.

Eu acho que, depois da Constituição Federal, a história de que educação é um direito da criança, não é uma coisa qualquer estar escrito isso na Constituição, é um grande avanço. É muito importante. E isso foi dando força aos movimentos. E, em 1993, o próprio MEC vai estimular muito a discussão de creche como parte da educação. $O$ fato até de começar a discutir que eles vão entrar nas estatísticas. Isso não é uma coisa qualquer. E, efetivamente, essa briga vai gerar um movimento interessante, que, apesar de o FUNDEF considerar os recursos exclusivamente para o ensino fundamental, as mães continuaram seu movimento no sentido de reivindicar educação infantil para seus filhos. Eu acompanhei o FUNDEF, acompanhei o Paulo Renato, ministro da educação nos Governos FHC 1 e 2, porque eu era membro da UNDIME nacional.

\section{Fineduca: Conta os bastidores...}

É. Você sabe que eu brincava com ele sobre aquela música: "Para onde você for, eu vou também. Eu sem você não sou ninguém", mas eu cantava só a primeira parte da letra quando estávamos presentes nas reuniões dele com os prefeitos. O Paulo Renato foi muito competente e, obviamente mentiroso, porque ele dizia textualmente que o dinheiro que viria, não só daria para eles, os prefeitos, municipalizar o ensino fundamental, como também sobrariam recursos para o município. Ele chamava os prefeitos, ele não chamava os secretários de educação. Até porque ele achava que metade eram mulheres e elas não decidiriam essa questão. Cada ministro que nós tivemos. Então, ele dizia que o dinheiro seria suficiente até para eles fazerem alguma coisinha. "Sabe, aquela estradinha que você quer fazer? Também cabe". E a gente ia para dizer: "Olha, não é bem assim". Cuidado, não é isso que está escrito no Projeto de Lei.

Fineduca: Que o piso salarial ia ser de 300 reais, não é, e não a média?

Exato, mas nós tínhamos professores no Nordeste, contratados como aquelas frentes de serviço de estrada, quer dizer, que ganhavam 150 reais por mês. Então, você tinha distorções graves, mas você já tinha caminhado para uma ideia de um piso para o magistério, que era alguma coisa que o Barjas Negri, um dos idealizadores do FUNDEF, ele também era muito articulado para conversar. Era ele que conversava com os secretários de educação, ele conversava conosco, certo? O Paulo Renato só com os prefeitos. E a gente ia para dizer: "Olha, cuidado que as coisas não são bem assim". E aí, entra o FUNDEF, que foi a política que o PSDB considerava mais importante na educação e que eu considero uma contradição, a maior contradição do governo deles foi ter mantido o FUNDEF com o mesmo valor de R\$ 300 por aluno no segundo ano de vigência. Porque aí eles perderam a legitimidade. 
É a mesma coisa aqui que fez o Bruno Covas $^{16}$, de esconder os dados da pandemia, e o Dória, e, no dia seguinte à eleição, divulgar os dados. E, também, porque ele prometeu uma gratificação às professoras de creches comunitárias na véspera da eleição. Na véspera da eleição! Filmado, fez a reunião na sexta-feira, eleição era domingo, prometendo 1.500 reais de complementação para elas. Nem poderia ter proposto isso porque é inviável e ilegal; a verdade é que elas estão vendo agora que nem pode, porque elas são terceirizadas, são funcionárias de outro lugar (funcionárias de empresas), nunca o governo poderia fazer isso, teria que alterar todos os contratos que existem. Mas foi assim que ele conseguiu os votinhos que ele precisava.

Então, eu quero dizer que também o PSDB não tem limite, e eles venderam a ideia como sendo a ideia que a política de fundos era mais justa. E eu dizia para o Paulo Renato: "Crie um fundo nacional e eu fico quieta. Enquanto for fundo estadual, não, porque você vai dividir a miséria com os miseráveis". Era um pouco isso, sempre foi a minha ideia, que era absolutamente injusto. Inclusive, uma prefeitura que conseguiu - por trabalhinho, que não é simples levar uma indústria e tal -, conseguiu levar uma indústria, ela vai ter que dividir com os outros e o outro lá é só o primo do prefeito da cidade ao lado. Eu às vezes falava: "Olha, gente, mil municípios aqui podiam ser fechados". Hoje eu já tomo cuidado quando eu falo isso, porque talvez não seja mais o caso. Mas, na época, lembre-se que, com a Constituição Estadual, ainda se pôde criar municípios e foram criados, entre a Constituição Federal e as estaduais, mais de mil municípios. Estes, com poucas exceções, eu teria eliminado, porque foram negociações daquele tipo: "Coloca aí. Na última hora, você tem o meu voto". E se colocou, mas um município de 3 mil pessoas, com Câmara Municipal, é uma coisa estranha.

Você poderia ter distrito, é que nós maltratamos muito os distritos, então falar distrito é pejorativo. Eu vejo lá onde está a UNICAMP, as pessoas querem que Barão Geraldo se transforme em um município, não pode ser distrito. Não é bem assim. Se você tem condição de sobrevivência financeira, ok, se você não tem, não pode ser município. "Querido, qual é o problema de ser distrito?". Sousas, em Campinas, também quer deixar de ser distrito, e é a mesma história aqui em São Paulo, com os distritos que tinha. Então, eu estou colocando isso porque eu acho que foi uma falcatrua, eles jogaram muito bem, tinha uma divulgação brilhante do FUNDEF.

Eu também quero dizer para vocês que eu não condeno um prefeito que aceitou a municipalização porque o ministro disse: "Olha, vai cair um dinheirinho". Para o cara que está sem nenhum tostão, que é pobre, o município e o prefeito é sério, ele vai topar. Ele fala: "Não, não é mau também dar aula para as crianças, é bom. Então, vamos municipalizar". Concretamente, porque essa ideia de que a gente mora na cidade e que a gente vive a cidade, ela é muito forte, porque é a nossa verdade. Então, é fácil defender a municipalização nesse sentido de que eu estou prestigiando onde você mora, de onde você é, onde você está, onde você se diverte, chora, ri, evolui. É isso.

Fineduca: O interessante, Lisete, é que na discussão da lei não se falava em municipalização. Ela veio meio por baixo do pano, não é? Depois, inverteu, o Paulo Renato só falava da municipalização. Isso, depois das eleições de 1996. Uma coisa é aprovar o projeto. O discurso era um: "Vem um dinheirinho e tal". Depois das eleições, no ano seguinte, tem uma coisa, quem votou, votou

16 Prefeito de São Paulo, gestão 2021-2024. 
e aí não estava mais. E o prefeito, que também concordou, ele já não era mais prefeito. Então, isso é uma história para se contar, porque você teve eleições. Fernando Henrique foi reeleito exatamente em 1998. Então, em 1998 ainda tem o discurso, mas ele, depois que é reeleito, acabou a história. Aí ia municipalizar. E aí faz como a Rose Neubauer (secretaria de educação estadual na época) fez aqui, com mais competência e agressividade, porque ela, ainda foi no SEADE (Fundação Sistema Estadual de Análise de Dados), pegou uns dados financeiros e habitacionais, e ela chamou cada prefeito. Ela chamou o Filippi, prefeito de Diadema, vim eu. Viemos Filippi e eu. Então, não pôde fazer grandes coisas, mas você imagina, era assustadora a maneira como ela apresentava os dados e dizia: "Olha, pela LDB, você tem que aceitar aqui o número de alunos que o seu orçamento permite..." e dizia: "O seu orçamento é tanto, vale tanto". E parte ela também inventava, não estava nem aí, você entende?

Fineduca: Havia aquela secretária de Descalvado, a Rute, que virou cabo eleitoral da municipalização em SP...

Só que a secretária de Descalvado era espertinha, porque eu também passei por Descalvado e, quando cheguei lá, ela teve que me contar - algo que eu divulguei bastante - que eles só tinham municipalizado $30 \%$, "Olha, o PSDB municipaliza isso que nós estamos falando para vocês, mais que $30 \%$, vai a $33 \%$. Mais que $33 \%$, não é questão de ser cabalístico, você começa a ficar ferrado. Você não vai conseguir manter plano de carreira, não vai conseguir manter as escolas limpas, abertas e tal. Cuidado, Descalvado municipalizou $30 \%$, então siga o PSDB, municipalize 30\%". A gente achava que 30\% dava. Até $30 \%$ dava.

Fineduca: E no caso de Descalvado, como era pequeno o município, a secretária estadual cedeu os professores e não cobrou o ressarcimento dos salários dos professores pelo município. Então, foi um "negocião".

Isso, igual Jundiaí. A diferença é que Jundiaí é rico. Mas em Jundiaí também, que o secretário de educação era da UNDIME (União Nacional dos Dirigentes Municipais de Educação) junto comigo, ele falou para mim: "Venha ver aqui como os professores estão felizes". Municipalização total, está certo? Claro, ele pagava a complementação do estado para os professores. E aí, o que acontece? Os professores do estado pediram, brigaram até com a APEOESP (Sindicato dos Professores do Ensino Oficial do Estado de São Paulo) na época, pediram para ser professores municipais. E eu falava para eles: "Cuidado, porque eles vão ceder, mas você vai ser cargo em extinção, porque vai ter que pôr outro lá efetivo no seu lugar, porque isso aqui é uma coisa para sempre. Então, cuidado, porque você também vai perder as promoções do estado".

Mas, como o secretário falou, o salário que o município pagava era maior que o do estado, e como o município era rico e podia pagar a diferença para os professores, ele pagou - e pagou, está certo? -, e as escolas eram bem cuidadas em Jundiaí, bom, era o que a Rose precisava para fazer propaganda da municipalização. E aí, tinha Santos, que nós tínhamos o contrário. Lembre-se que em Santos nós entramos em debate com o David Capistrano, prefeito na época, que era um grande municipalista. Nós conseguimos aprovar no PT um parecer contra a municipalização, mas o Davi Capistrano falava que se o município tivesse condições era bom municipalizar as políticas sociais. Ele tinha razão em uma coisa, Santos é o município no estado de São Paulo que tem o maior percentual de recursos próprios, porque tem 500 mil 
pessoas morando e tem 500 mil que vão lá gastar dinheiro em pelo menos três meses do ano. Segundo, tem o maior porto do Brasil. E, terceiro, tem o petrolinho jorrando do lado. Então, bom, desse jeito é verdade, Santos podia falar, talvez seja o município que mais pudesse falar em municipalização.

Sobre esse aspecto, o Davi Capistrano estava certo, mas o problema era o efeito indutor, a primeira bola de neve que nós não queríamos que acontecesse. Ele acabou municipalizando e ponto final, mas, do ponto de vista concreto, a Rose obrigou aqui em São Paulo e nos outros lugares a municipalizar. O CONSED teve uma participação importante também. Eu diria que o CONSED, com todo respeito, na maioria da sua existência, ele foi do mal, em relação aos municípios, porque ele pensou nas redes estaduais exclusivamente e ele encabeçou esse movimento de municipalização, a ponto de chegar ao extremo, no estado de São Paulo, de a Secretaria Estadual de educação centralizar todas as matrículas. Isso é o fim da picada, porque eles matriculam quando eles querem matricular, com a perda, inclusive, da autonomia municipal, para essa questão, em um nível absurdo.

Eu acompanhei a luta da Lívia Maria Antongiovanni aqui em São Paulo (gestão Fernando Haddad, 2013-2016), para que, pelo menos, as matrículas nos cursos de alfabetização de jovens e adultos fossem feitas pelo município, já que o estado estava abrindo mão desse atendimento. Então, a surpresa também foi, antes, quando começou o governo Lula, bem, as coisas continuam em uma situação precária em relação ao FUNDEF, depois é que, quando começa a ter a defesa do FUNDEB, digamos, que os percentuais e a discussão sobre o piso vão trazer um certo diferencial para a educação. Tanto assim que você vê - do que eu me lembro, não tenho os dados aqui na mão -, 2015 vai ser o ano que mais se gastou em educação, e aí começa o decréscimo já em 2016. Quer dizer, eu estou dizendo isso porque eu tenho essa preocupação, Márcia e Zé, que é o seguinte, que os nossos políticos e dirigentes, educacionais e financeiros, não suportam a educação com dinheiro suficiente para dar conta do seu recado com qualidade.

A nossa história é uma história de cortes sistemáticos por diferentes razões. E vocês vejam que agora, mesmo em uma situação da pandemia, o governo atual vem cortando sistematicamente recursos para a educação, de bolsas de estudos a programas diversos da educação básica. É claro que ele é desqualificado e tal, mas ele está aí, firme e forte. E, efetivamente, ele tirou 2 bilhões da educação para transformar em dinheirinho para os deputados distribuírem. Tudo bem, eu quero respeitar os deputados, quero fazer também um pedido para que o dinheiro venha para a educação mesmo, agora é um absurdo que haja concordância que se tire dinheiro da educação para que seja gasto nessas propostas que, por mais meritórias, não justificariam que se tirasse da educação. Então, eu me preocupo, acho que 2021 vai ser um ano de guerra. Não de luta, de guerra, porque as universidades federais vão sentir um baque direto. Nós aqui em SP, com a USP (Universidade de São Paulo) e a FAPESP (Fundação de Amparo à Pesquisa do Estado de São Paulo) e o PSDB nas três universidades paulistas, tem muito PSDBista aqui dentro, tem muito PSDBista na FAPESP, o Dória não podia entrar em cima, mas vocês veem que ele também cortaria os financiamentos, caso o PL encaminhado por ele tivesse sido aprovado.

Se a gente não age aqui, nós poderíamos ter perdido a nossa autonomia e, inclusive, essa foi uma sacanagem feita com a maior naturalidade. Como se ele pudesse misturar todas as coisas que ele misturou no mesmo pacote fiscal. Então, eu tenho essa preocupação. Bom, 
com o FUNDEF, eu sou obrigada a admitir, a educação infantil não perdeu tanto, mas porque a realidade social obrigou que ela não perdesse tanto. Os movimentos feministas hoje são mais fortes, mais barulhentos e mais organizados do que eram 30 anos atrás. Então, nós estamos chegando. E aí, também a questão das creches, elas ganharam uma dimensão lúdica, educativa, que elas nunca tiveram. Você tem excelentes exemplos de creches públicas que estão fazendo um ótimo trabalho. Então, é difícil também destruir simplesmente um trabalho que é bem feito.

Fineduca: Lisete, na sua linha de dividir em fases; antes de Alagoas, depois de Alagoas, antes de Diadema, depois; pode-se dizer que existe a educação brasileira, do ponto de vista do sistema federativo, antes e depois do FUNDEF? Porque houve um deslocamento gigantesco de matrícula. Dá para dizer isso?

Dá sim e com um problema. Os estados não fizeram nenhum movimento para ampliar o ensino médio. Ele tem um crescendo, termina em 2002 e fica lá. Então, eu diria que o FUNDEF foi uma desresponsabilização dos estados em relação à educação. Essa é uma coisa que pode ser triste, mas que nós temos que admitir. Não é verdade que eles investiram na educação deles, os professores continuam ganhando mal, as escolas estão feias, estão cheias de grade, caindo aos pedaços. Precisa de tudo, pintura, grandes e pequenas reformas, precisa de boa merenda. Não é verdade que nem as merendas foram melhoradas com isso. Então, eu diria que não mudou muito, pois, o município continua responsável pela maior fatia da educação e foi um absurdo precisar que se escrevesse na LDB que, se é o município que transporta criança do estado, é o estado que tem que pagar. Aqui, nós tivemos aquela falcatrua do Alckmin ${ }^{17}$, que pôs todo o dinheiro gasto com o metrô para dizer que era transporte de aluno, mas, do ponto de vista concreto, os municípios até hoje são onerados com a merenda escolar para os alunos da rede estadual. Podemos falar que São Paulo, Campinas, Sorocaba, Santos, Jundiaí conseguem oferecer uma boa alimentação. Agora, quando você vai para o interior do Brasil, você vê que, ou o município distribui lá umas laranjinhas e uns pãezinhos, ou não tem merenda nas escolas estaduais. O dinheiro, que é transferido pelo MEC para merenda escolar, ele é ridículo do ponto de vista de custo real.

Mesmo comprando bem, comprando no mais barato, mesmo fazendo menu médio do ponto de vista de elementos in natura e não in natura, é um dinheiro que é decididamente insuficiente. Então, ou os municípios bancam ou, realmente, as crianças não comem no Brasil. Eu acho que isso é uma questão, essa desresponsabilização, essa transferência sumária de responsabilidades, ela é um fato. Com o FUNDEB, a coisa não fica diferente, porque a lógica é a mesma. Nós estamos vendo aí a cada dia, e eu quero dizer isso porque primeiro eles forçaram que você municipalizasse da primeira à quarta série, que é um procedimento que, no Brasil, tem uma certa generalização, mas o ideal para eles é municipalizar o ensino fundamental inteiro. O que não significa um maior investimento no ensino médio.

E eu levanto aqui como hipótese para estudos, porque ainda estou pensando no assunto, mas eu fiquei um pouco impressionada, quando o Michel Temer entrou (2016), com a rapidez com que o PSDB quis fazer a reforma do ensino médio. Toda vez que o PSDB é rápido, a gente desconfia, porque tem falcatrua por trás. E, efetivamente, eu não tenho dúvida nenhuma que,

17 Geraldo Alckmin foi governador do estado de São Paulo nos períodos de 1995-2001, 2002-2006, 2011-2018. 
para mim, eles falam: "Olha, não dá para... no Brasil, nem tem gente interessada em privatizar o ensino fundamental. Nós vamos fazer desse jeito que a gente está fazendo, põe as assessorias, consultorias, deixa o índice do IDEB (Índice de Desenvolvimento da Educação Básica) ser o grande indicador que não deixa os prefeitos dormirem, porque eu tenho que subir, tem que subir no IDEB, deixa os privados lá ganharem o seu dinheiro, mas deixa o ensino fundamental como estatal. Mas o ensino médio não; o ensino médio pode ser nosso". Eu não consigo nem entender, confesso que eu tenho dificuldade. Eu leio a lei e me pergunto: quem escreveu isso?

E quando eu vejo a BNCC do ensino médio, a certeza se consolida, porque ninguém faz aquela brincadeira de você apresentar Português e Matemática e, depois, apenas nove paginazinhas lá de humanas e exatas, digamos assim, do jeito que foi feito sem ter sido preso ou morrido. Quer dizer, se tivesse ocorrido um tsunami lá no MEC e essas pessoas tivessem desaparecido, não deu para acabar o discurso, eu até entenderia aquele documento. Mas elas estando vivas e fortes e uma delas ser presidente do Conselho Nacional de Educação ainda, chamada Maria Helena Castro, é demais. Se a Guiomar continuar aqui com a Rose, continuarem no Conselho Estadual de Educação, é demais. É destruição do ensino médio sem nenhuma preocupação de articulação. Você vê que esse negócio de projetos; eu acho que isso é uma invenção maluca que fizeram de desvio de dinheiro, para chamar o privado para dentro da escola. Agora, nós não temos nada, não tem nenhum dispositivo sobre Física, Química, Biologia, Sociologia, Filosofia, está certo? Nada disso. Então, como é que vai fazer a formação dos nossos jovens? Quer dizer, que país é este? Vai para onde?

Fineduca: Há ainda a tentativa de introdução do sistema 'S' no novo FUNDEB, que se articula muito com esses interesses.

Exatamente. Outra coisa que foi muito forte, que eu confesso que me deixou com mal-estar, até pelas pessoas que participaram, foi quebrar a ideia de que a educação básica é um direito de todos. Eles fizeram o que fizeram e está aí a BNCC para ser cumprida para todos. Não vou nem discutir os absurdos, que eu já discuti o suficiente, mas os conteúdos são absurdos, acaba a proposta de conteúdos ano a ano no nono ano do ensino fundamental, e o que vem depois é nada. Então, é preocupante.

E é nesse momento que se aprova o novo FUNDEB, com todas as condições que nós estamos vendo, eu ficava pensando que nós tínhamos que fazer um outro decálogo de obrigações do ensino médio, dos governos estaduais em relação ao ensino médio, do que o que está acontecendo. Porque aqui, por exemplo, em relação à alfabetização de adultos, cada dia estão fechando escolas. Você vai fazer o quê? Transferir para as comunidades as escolas de educação de jovens e adultos? Você está fechando, no estado de São Paulo inteiro, o período noturno. O que é isso? Eles acham que os jovens não trabalham? O caixa do supermercado não é um jovem que está ali sentado e que precisa estudar à noite, que trabalha, no mínimo, das 7 às 19h? Então, é incompreensível. Tivemos ganhos e a Campanha Nacional pelo Direito à Educação fez um excelente trabalho, insubstituível. Eu às vezes digo que a Campanha assumiu o papel que foi do Fórum Nacional de Educação em Defesa da Escola Pública historicamente. O que nós fomos antes, hoje é a Campanha, porque o movimento para derrubar as mudanças feitas a favor do setor privado, eu ainda estava em precárias condições de saúde aqui, acompanhava via zaps, mas foi maravilhoso. O Brasil 
inteiro, quer dizer, esses professores e essas professoras, os alunos, não deram paz para os deputados, foi muito bonito. A regulamentação, a gente sabia, ia ser de pior para pior. Então, eu cumprimentei a Campanha, porque acho que vale o esforço, não ficou tão ruim quanto estava, mas ela é ainda uma porta aberta para a privatização, para os privados entrarem.

No ensino médio isso é evidente, porque aí a lei permite e eu acho que eles têm realmente projetos complicados em relação ao ensino médio. Tenho bastante preocupação, acho que logo a gente vai ter que fazer um movimento nacional em defesa de alguma coisa chamada "ensino médio", que não seja isso que está aí. Mas eu vejo, por exemplo, que acabamos aceitando a questão do mérito e do rendimento dos municípios no novo fundo. Já vou ficar feliz com o que conseguimos. Mas é verdade, eu acho que a lei do fundo, ao não definir prazo, um limite para o setor privado, está, sim, estabelecendo, como política nacional, que creche é comunitária. Isso eu acho que nós vamos ter que esperar o próximo governo, que a gente espera que não seja o mesmo, mas eu acho que essa é uma alteração que a gente tem que fazer. E, obviamente, está aberto para qualquer empresa entrar para as escolas, não está escrito "SENAl", "SENAC" lá, mas está autorizado a entrada de empresas.

Então, eu diria que uma política de fundos, é mais difícil de você controlar do que na minha velha proposta de reforma tributária, que levaria a que você estabelecesse um percentual que contemplasse um percentual que compensasse as desigualdades nacionais e regionais do Brasil. A relação dos municípios com o Tribunal de Contas também é uma coisa complicada, mas, se nós conseguirmos ter conselhos que comecem a realmente discutir financiamento, podemos ter avanços significativos. De toda forma, reconheço que nós estamos muito melhores. Porque quando nós começamos, Zé, eu não sei se você se lembra, no primeiro projeto que a gente fez para estudar o FUNDEF em 1998, a gente ia para os municípios e o secretário de finanças falava com a maior cara de pau: "Não, nós cumprimos as exigências do Tribunal, os demonstrativos dos gastos com os $25 \%$ estão pendurados". Sim, mas estava pendurado atrás da porta da sala dele. E, óbvio, ninguém entrava na sala dele. Ainda hoje, é mais difícil falar com o secretário de finanças do que com qualquer prefeito. Até aqui em São Paulo, você fala com o Bruno Covas, mas você não fala com o secretário de finanças. Então, a gente sabe que eles são os deuses. Então, eu diria que a gente está melhor, pois o cara é obrigado a apresentar os $25 \%$ e, se ele mente, o Tribunal de Contas também tem todas as condições de verificação. O Tribunal de Contas também mudou, porque hoje você pode fazer pesquisa lá e eles são aliados, os técnicos. Porque também aprendemos com os técnicos; eles dizem o seguinte: "Olha, na hora da reunião deliberativa do Tribunal de Contas tem a negociação deles, então tem município que a gente deu parecer contra e que vai ser ignorado, eles vão aprovar, mas tem uns tantos que são perguntados". E isso vai melhorando, porque cada um que cai, é pedagógico, desestimula outros a fazerem a mesma coisa.

Então, eu diria que hoje, em financiamento da educação, nós não estamos mais no ponto zero. E a discussão do FUNDEF, assim como a discussão do FUNDEB, tem esse mérito. Eu vou dizer depois a minha posição. Mas o FUNDEB obriga uma discussão sobre financiamento da educação. Então, esse é o lado positivo. O que eu já disse, realmente tenho muitas dúvidas, é para onde vai a política de fundos. Eu considero - e você sabe que eu já defendi em público como presidente da FINEDUCA -, eu fui lá na Câmara dos Deputados e falei: "Bendito FUNDEB". Por quê? Por uma circunstância, não porque eu defenda o FUNDEB no 
coração, não, mas porque ele ficou fora da Emenda Constitucional 95. Então, ele é um dinheiro que a gente tem, o único dinheiro que a gente tem garantido para a educação.

Então, sob esse aspecto, eu diria que a Emenda Constitucional 95, quem escreveu esse pedacinho [que isenta a complementação federal dos limites da EC 95], talvez a tenha escrito exatamente para poder passar. A EC 95 é o pior ato legal, na minha opinião, depois do Al-5. É verdade que eu falo que houve ainda a Emenda Constitucional 19/1998, feita pelo BresserPereira - por isso que até hoje eu tenho muita dificuldade de considerar o Bresser-Pereira um democrata, um progressista, porque foi ele que abriu a porta da privatização para o pensamento neoliberal se instalar em definitivo aqui. A partir daí nem toda tarefa do Estado precisa ser feita pelo Estado e, segundo, transformou em constitucional o repasse de dinheiro público para o privado.

Daí em diante se instala a disputa pelo dinheiro público em todas as suas instâncias e as privatizações são um mecanismo. Nós estamos vendo aí o que acontece com as privatizações. Estou vendo aí o último derramamento de petróleo, você, Zé, que defende o meio ambiente, eu também, mas você tem um programa só para isso. $\mathrm{O}$ último derramamento que teve, por absoluta incompetência da BR privatizada, é uma coisa que devia servir de exemplo para todos nós. O que a Vale fez em Brumadinho é um absurdo. Gostei até que o prefeito lá suspendeu a autorização deles. O que fizeram na Amazônia, quer dizer, é um negócio maluco o que os privados, o que os mercenários no Brasil e do Brasil fazem.

Então, eu tenho essa questão, hoje eu defendo o FUNDEB provisoriamente, enquanto durar a Emenda Constitucional 95, eu o estarei defendendo, mas eu tenho a preocupação de para onde ele vai. $O$ fato de hoje nós dizermos que até teve uma atualização, teve uma atualização relativa, porque a educação está perdendo dinheiro anualmente. Então, também as possibilidades desse gradativo é cada vez menos gradativo e mais igual. Então, eu vejo como tendência, se a gente não tiver força política e social no Brasil, o risco de caminharmos para o voucher, ou qualquer outra fórmula, que defenda uma educação mais barata, é para lá que nós vamos. O que é pior, porque uma educação mais barata será para os pobres, e a educação de qualidade, que deve ser para todos, será para alguns. Vejo isso como preocupação em relação ao momento que nós estamos vivendo.

Lisete Regina Gomes Arelaro é Pedagoga e Doutora em Educação. Foi professora e diretora de escola nos ensinos fundamental e médio. Fez parte da equipe do Prof. Paulo Freire na Secretaria Municipal de Educação de São Paulo (1989/92) e foi Secretária de Educação, Cultura, Esporte e Lazer em Diadema/SP (1993/96 e 2001/02), Diretora da Faculdade de Educação da USP (2010/2014), Presidente do Fórum Nacional de Faculdades e Centros de Educação Públicos (FORUMDIR - 2012/2014) e presidente da Associação Nacional de Pesquisa em Financiamento da Educação (FINEDUCA - 2015/2017). Atualmente é Professora Titular Sênior da Faculdade de Educação da USP, e pesquisadora na área de Política Educacional, Planejamento e Avaliação Educacional, Financiamento da Educação Básica e Educação Popular.

ORCID: https://orcid.org/0000-0001-7581-8622

E-mail: liselaro@usp.br 


\section{Editores do volume 11}

Márcia Aparecida Jacomini - Universidade Federal de São Paulo, Brasil

José Marcelino de Rezende Pinto - Universidade de São Paulo, Brasil

\section{Comitê Editorial}

Nalú Farenzena - Universidade Federal do Rio Grande do Sul, Brasil

Juca Gil - Universidade Federal do Rio Grande do Sul, Brasil

Theresa Adrião - Universidade Estadual de Campinas, Brasil

Ângelo Ricardo de Souza - Universidade Federal do Paraná, Brasil

\section{Conselho Editorial}

\section{Alejandro Morduchowicz}

Universidad Pedagógica, Provincia de Buenos Aires, Argentina

Andréa Barbosa Gouveia

Universidade Federal do Paraná, Brasil

Fernanda Saforcada

Universidade de Buenos Aires, Argentina

Jacques Velloso

Universidade de Brasília, Brasil

João Monlevade

Senado Federal, Brasil

Jorge Abrahão de Castro

Instituto de Pesquisa Econômica Aplicada / IPEA, Brasil

Lisete Regina Gomes Arelaro

Universidade de São Paulo, Brasil

Luis Carlos Sales

Universidade Federal do Piauí, Brasil

Luiz de Sousa Junior

Universidade Federal da Paraíba, Brasil

Luiz Fernandes Dourado

Universidade Federal de Goiás, Brasil

Magna França

Universidade Federal do Rio Grande do Norte, Brasil

Marcos Edgar Bassi

Universidade Federal de Santa Catarina, Brasil

Maria Angélica Pedra Minhoto

Universidade Federal de São Paulo, Brasil

Maria Beatriz Luce

Universidade Federal do Rio Grande do Sul, Brasil

Maria Dilnéia Espíndola Fernandes

Universidade Federal de Mato Grosso do Sul, Brasil

Nelson Cardoso do Amaral

Universidade Federal de Goiás, Brasil

Nicholas Davies

Universidade Federal Fluminense, Brasil

Robert E. Verhine

Universidade Federal da Bahia, Brasil

Romualdo Portela de Oliveira

Universidade de São Paulo, Brasil

Rosana Gemaque Rolim

Universidade Federal do Pará, Brasil

Rubens Barbosa de Camargo

Universidade de São Paulo, Brasil

Theresa Adrião

Universidade Estadual de Campinas, Brasil

Tristan McCowan

University of London, Reino Unido

Vera Jacob

Universidade Federal do Pará, Brasil

Vera Peroni

Universidade Federal do Rio Grande do Sul, Brasil

Vitor Henrique Paro

Universidade de São Paulo, Brasil

\section{Equipe editorial}

Apoio ao Comitê Editorial: Caio Cabral da Silva

Diagramação, Revisão de português e normalização: Edson Leonel de Oliveira

Revisão de inglês: Sabrina Ferreira

Fineduca - Revista de Financiamento da Educação

Associação Nacional de Pesquisa em

Financiamento da Educação

e-mail: revista.fineduca@gmail.com | site: http://seer.ufrgs.br/fineduca 